\title{
The Effect of Linguistic Knowledge and Korean Phonotactic Probability on Nonword Repetition and Fast Mapping Ability
}

\author{
Kyeongran Bae, Dongsun Yim \\ Department of Communication Disorders, Ewha Womans University, Seoul, Korea
}

Correspondence: Dongsun Yim, PhD Department of Communication Disorders, Ewha Womans University, 52 Ewhayeodae-gil, Seodaemun-gu, Seoul 03760, Korea

Tel: $+82-2-3277-2120$

Fax: +82-2-3277-2122

E-mail: sunyim@ewha.ac.kr

Received: April 20, 2018

Revised: May 23, 2018

Accepted: May 23, 2018

This work is based on the master's thesis of the first author (2018).

\begin{abstract}
Objectives: The present study aimed to discover whether specific variables correlated with performance of non-word repetition (NWR) and fast mapping (FM) in each group, and whether the mean score of correct response per non-word correlated with each biphone phonotactic probability (PP) in the NWR and FM comprehension task of each group. Methods: Fifteen children with specific language impairment (SLI) and 20 age-matched children with normal language (NL) from 4- to 6-year-old participated in this study. We performed NWR and FM tasks according to wordlikeness by adjusting biphone PP. Two-way mixed ANOVA and Pearson correlation coefficient were used to analyze the data. Results: The main effect of the group was significant in all tasks. In NWR and FM comprehension, the main effect of wordlikeness was significant. There was no interaction in any task. Also, the SLI group showed significant correlation between NWR, age, receptive, and expressive vocabulary. The NL and SLI groups showed significant correlation between mean score per non-word item and each non-word biphone PP in the NWR, and only the SLI group showed significant correlation between mean score per non-word item and non-word biphone PP in FM comprehension. Conclusion: The results indicate that Korean language is also affected by PP. In addition, an advantage of high wordlikeness is that the NWR and FM, which are known to tap underlying language processing, are affected by Korean PP, and that both NL and SLI are influenced by linguistic knowledge. These results suggest the need to consider PP in evaluation and intervention with Korean non-words.
\end{abstract}

Keywords: Wordlikeness, Phonotactic probability, Linguistic knowledge, Nonword repetition, Fast mapping, Preschool-age
Leonard (2014)의 정의에 의하면, 단순언어장애(specific language impairment)란 인지, 신체, 감각, 정서 및 신경학적인 장애의 동반 없이 언어 습득에 어려움을 보이는 것으로 언어발달 과정 중에 이 러한 문제를 보이는 아동을 단순언어장애 아동이라고 일컫는다. 여러 연구들을 통해 밝혀진 단순언어장애 아동의 음운인식, 음운 기억 능력의 결함(Baddeley, Gathercole, \& Papagno, 1998; Botting \& Conti-Ramsden, 2001; Kang \& Kim, 2007), 낱말 찾기 및 습득의 어려움(Kim, 2004; Yang, Yim, Kim, \& Han, 2013) 등의 특성들은 언어발달 지연의 원인이 되며, 이후 읽기와 쓰기, 학습영역에서 부 진으로 이어지는 원인이 된다고 알려져 왔다(Bishop \& Adams,
1990; Gathercole \& Baddeley, 1993; Leonard, 2014; Mackie \& Dockrell, 2004). 이러한 연구결과들은 언어발달 초기에 정상 발달하는 아동 집단과 단순언어장애 아동 집단의 수행을 비교함으로써 기저 의 언어처리 기제의 결함을 밝히고, 적절한 중재를 제공하는 것의 필요성을 강조한다.

언어 기저의 처리 능력을 측정하는 과제의 종류는 매우 다양하 며, 그 중 많이 쓰이는 것으로 알려진 것이 음운 단기기억 능력을 측 정하는 비단어 따라말하기와 새로운 어휘의 이해와 산출 능력을 측정하는 빠른의미연결 과제이다(Gathercole, 1995; Gray, 2004). 비단어 따라말하기(nonword repetition)는 무의미 음절을 들려주 
Kyeongran Bae, et al. • The Effect of Linguistic Knowledge and Korean Phonotactic Probability

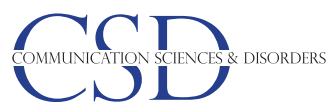

고 즉각적으로 따라 말하도록 하는 과제이며(Gathercole, 1995), 새 로운 단어의 음운 정보의 표상을 형성하고 일시적으로 저장 및 유 지하는 처리 단계들을 거쳐 수행된다(Baddeley, 2003). 빠른의미연 결(fast mapping)은 한두 번의 노출 후 시간적 간격을 두고 새로운 단어와 지칭하는 대상을 연결 지을 수 있는 능력을 측정하는 과제 로(Rice, Buhr, \& Nemeth, 1990) 한 번의 기회가 제공되고 즉각적 으로 인출해야 하는 비단어 따라말하기와는 다르다. 그러나 빠른 의미연결 과제가 청각적으로 제시된 말소리 정보들을 지각하고 음 운적 및 의미적 표상을 형성, 연결, 저장하는 여러 하위 처리 단계들 로 구성된다는 점에서 비단어 따라말하기와 유사하다. 또한, 두 과 제 모두 아동의 장기기억 속에 존재하는 실제 어휘가 아닌 비단어 를 사용함으로써 언어의 선행지식의 영향을 받지 않고 순수한 기 억 능력, 어휘학습 능력을 측정할 수 있다는 공통점이 있다(Carey, 1978; Dollaghan, 1985; Dollaghan \& Campbell, 1998).

이전의 많은 연구들은 비단어 따라말하기, 빠른의미연결 과제를 사용하여 언어 기저의 하위 처리 과정에서 정상 발달하는 일반아동 과 언어장애 아동 간의 수행 차이를 살펴보고자 하였다(Archibald \& Gathercole, 2007; Alt, Plante, \& Creusere, 2004; Gray, 2003a; Weismer \& Hesketh, 1996; Weismer et al., 2000). 다수의 연구들은 정상 발달하는 또래 아동에 비해 단순언어장애 아동이 비단어 따 라말하기에서 유의하게 더 낮은 수행을 보이며, 음절의 길이가 길어 질수록 수행이 낮아진다는 일관적인 보고를 하였다. 이는 단순언어 장애 아동의 제한된 음운기억용량과 새로운 음운 표상의 저장에 서 보이는 어려움이 밀접한 관련이 있음을 나타낸다(Dollaghan \& Campbell, 1998; Edwards \& Lahey, 1998; Gathercole, 2006; Gathercole \& Baddeley, 1990a, 1990b). 빠른의미연결과 관련한 많은 연 구의 결과에서도 단순언어장애 아동이 정상 발달하는 일반아동 에 비해 유의하게 낮은 어휘학습 능력을 보이는 것으로 보고하였다

(Gray, 2003b, 2004; Rice et al., 1990; Rice, Buhr, \& Oetting, 1992). 이는 최소한의 노출 후 단기적으로 저장된 의미적, 음운적 표상들 이 리허설, 충분한 자극의 양과 같은 추가적인 지지 수단 없이는 유 지되기 어려우며, 단순언어장애 아동의 경우 불안정한 표상이 손 실될 가능성이 더 높다는 주장들(Baddeley, 2003, 2012; Ellis, 1996; Gray, 2006)을 뒷받침한다. 또한, 아동(Alt et al., 2004; Jackson, Leitao, \& Claessen, 2016) 뿐만이 아니라 성인 집단(Baddeley et al., 1998; Gupta, 2003)에서 보인 음운 단기기억과 어휘학습 능력 간의 상관 관계는 새로운 음운 정보를 저장 및 유지하는 데 음운 단기기억 능 력이 중요한 역할을 한다는 것을 제시한다. 이렇듯 언어 정보의 처 리 능력을 측정하며, 기저의 처리 기제 결함을 선별 가능하게 하는 비단어 따라말하기와 빠른의미연결은 단일언어를 습득하는 아동
집단에서뿐만이 아니라 다양한 언어적, 문화적 환경에서 언어를 습득하는 집단에서도 단순언어장애 아동들을 선별하기 위한 방법 으로 활발히 권유되어 왔다(Hong \& Yim, 2014; Windsor, Kohnert, Lobitz, \& Pham, 2010).

그러나 최근 여러 연구에서 밝혀진 수용어휘력과 비단어 따라 말하기, 수용어휘력과 빠른의미연결의 수행 간의 상관관계가 어린 아동들이 새로운 단어의 음운 표상을 확립하는 데 장기기억에 저 장된 어휘지식의 도움을 받는다는 것을 보여주는 것과 동시에 비 단어 따라말하기와 빠른의미연결에서 단순언어장애 아동의 낮은 수행이 기저의 처리 메커니즘의 결함에 부족한 어휘지식의 영향이 더해져 비단어의 음운 표상을 형성하는 과정에서의 어려움을 나타 내는 것이라는 주장이 생겨나기 시작했다(Gathercole \& Baddeley, 1989; Gray, 2004; Munson, Kurtz, \& Windsor, 2005; Roy \& Chiat, 2004). 따라서 다수의 연구자들이 비단어 따라말하기와 빠른의미 연결 과제의 수행에 영향을 미치는 요인들을 밝히고자 하는 노력 을 시도하였다. 그리고 비단어의 음운 정보를 처리하는 데 영향을 미치는 요인으로 이웃밀도(MacRoy-Higgins, Schwartz, Shafer, \& Marton, 2013; Storkel, 2004), 조음복잡성(Bishop, North, \& Donlan, 1996; Gallon, Harris, \& Van der Lely, 2007), 단어유사성(Gathercole, Willis, Emslie, \& Baddeley, 1991; Lee, Kim, \& Yim, 2013) 등 을 밝혀냈다.

그 중, 이웃밀도(neighborhood density)는 특정 어휘와 음운적 으로 유사한 어휘의 수의 정도를 나타내며, 유사한 어휘가 많을수 록 이웃밀도가 높아진다. 이웃밀도와 관련하여 몇몇의 연구에서는 어린 아동들이 이웃밀도가 낮을수록 더 나은 어휘학습 능력을 보 고하였으나(MacRoy-Higgins et al., 2013; McKean, Letts, \& Howard, 2013) 일부 연구에서는 이웃밀도가 높은 단어가 낮은 단어에 비해 더 높은 수행을 보인다는 상이한 연구결과를 보고하였다. 그 밖에 다른 연구에서도 과제의 종류, 연령 및 집단에 따라 이웃밀도 의 효과가 다르게 나타남을 보여주었으며(Gray, Pittman, \& Weinhold, 2014; Metsala, 1997; Vitevitch \& Luce, 1999), 이는 아직까지 일관적인 이웃밀도의 효과를 설명하기에는 논란의 여지가 있음을 보여준다.

조음복잡성(phonetic complexity)은 말 산출에 영향을 주는 조 음의 위치와 방법, 이중모음 및 종성의 유무 등을 나타내는 것으로 배점 기준에 따라 점수를 산출한다(Dworzynski \& Howell, 2004). Gallon 등(2007)에서는 단순언어장애 아동들이 비단어 따라말하 기에서 조음복잡성이 높은 비단어에서 낮은 비단어에 비해 유의하 게 더 낮은 수행을 보임을 밝혔으며, 다른 연구에서도 말 산출에 조 음복잡성이 미치는 효과를 증명하였다(Lee, Han, \& Sim, 2004). 
단어유사성(wordlikeness)은 비단어가 실재하는 특정 단어와 얼 마나 유사한지를 나타내는 것이 아닌 실제 단어들의 음운배열구조 와 유사한 정도를 의미한다(Gathercole, 1995; Gathercole et al., 1991). 따라서 단어유사성은 단어의 특정 위치에서 소리의 배열이 실제 언 어에서 발생할 수 있는 확률(Jusczyk \& Luce, 1994)을 뜻하는 음소 배열확률(phonotactic probability)과 불가분의 관계에 있다(Frisch, Large, \& Pisoni, 2000; Vitevitch, Luce, Charles-Luce, \& Kemmerer, 1997). 즉, 높은음소배열확률의 소리 연쇄로 구성된 비단어는 실 제의 언어에서 유사한 음소배열이 많으므로 더 실제 단어와 같이 인식되며, 낮은음소배열확률의 소리 연쇄로 구성된 비단어는 실제 의 언어에서 유사한 음소배열이 적으므로 실제 단어처럼 인식되기 어렵다는 것이다. 선행연구에서는 음소배열확률이 산출의 정확도와 단어 인식의 반응시간에 미치는 긍정적인 영향을 밝혔으며(Vitevitch et al., 1997; Vitevitch \& Luce, 1998), 비단어 따라말하기를 사 용한 다수의 연구들에서 높은음소배열확률의 비단어가 낮은음소 배열확률의 비단어에 비해 더 높은 수행을 보이는 것을 발견하였다

(Gathercole et al., 1991; Gathercole, Frankish, Pickering, \& Peaker, 1999; Van Bon \& Van Der Pijl, 1997). 이는 높은음소배열확률의 비 단어가 내재된 어휘 지식에서 유사한 음소배열의 단어들을 활성화 시켜 새로운 단어의 표상을 안정적으로 형성 및 저장하도록 돕는 반면, 음소배열확률이 낮은 비단어는 활성화시킬 수 있는 비슷한 음소배열의 단어가 적고, 불안정한 음운 표상을 형성 및 저장함으 로써 수행의 차이를 보인 것으로 설명할 수 있다(Edwards, Beckman, \& Munson, 2004; Munson, Edwards, \& Beckman, 2005; Zamuner, 2009).

한편, 말 산출에서 일관적으로 높은음소배열확률의 이점을 밝 힌 비단어 따라말하기와 다르게 빠른의미연결에서는 이해와 산출 의 측정 단계에서 음소배열확률의 효과가 각각 다르게 나타나는 것 으로 보고되었다(Gray et al., 2014; Storkel, 2003; Storkel \& Maekawa, 2005; Weismer, Venker, Evans, \& Moyle, 2013). 먼저, 빠른의미 연결의 이해 단계에서는 높은음소배열확률의 비단어를 낮은음소 배열확률의 비단어보다 더 많이 식별할 수 있는 것으로 보고되었 다(Storkel \& Rogers, 2000; Storkel, 2001). 이는 음소배열확률이 높 을수록 비단어의 의미적, 음운적 표상을 형성하고 연결하는 데 머 릿속의 어휘집(lexicon)에서 유사한 음소배열구조의 정보를 끌어 오기 쉽다는 것을 나타낸다. 빠른의미연결의 산출 단계에서는 정 상 발달하는 일반아동과 단순언어장애 아동 모두 낮은 점수로 집 단 간의 수행 차이 및 음소배열확률의 효과를 보이지 않았다는 보 고(Gray, 2006; Gray \& Brinkley, 2011)가 있는 반면에, 몇 번의 노출 후 적지만 높은음소배열확률에서의 효과를 보고한 연구결과도 있
다(MacRoy-Higgins \& Dalton, 2015; Storkel, 2001). 또한, 지속적인 단어학습 과정에서 음소배열확률의 효과를 살펴본 일부 연구에서 는 일반아동과 단순언어장애 아동들 모두 낮은음소배열확률에서 높은음소배열확률보다 더 나은 수행을 보인다고 밝혔다(Gray \& Brinkley, 2011; Gray, Brinkley, \& Svetina, 2012). 이에 대해 Hoover, Storkel과 Hogan (2010)은 충분한 자극을 줄 때 낮은음소배열확률 이 어휘집 내의 비슷한 음소배열의 단어가 적어 혼란을 덜 야기하 고, 독특한 음소배열구조가 오히려 음운 표상의 확립을 촉진시킬 수 있다고 언급하였다. 이러한 결과들은 비단어 따라말하기와 빠 른의미연결 과제가 비단어를 사용함으로써 언어의 선행지식에 편 향 없이 언어 기저의 처리 과정을 측정하는 것으로 알려져 왔으나 비단어가 실제 언어의 음소와 배열규칙에 따라 구성되므로 오히려 단어유사성이나 조음복잡성과 같은 음운적 특성에 영향을 받을 수 있다는 사실을 의미한다.

또한, 단순언어장애 아동과 또래의 일반아동에게 광둥어 비단어 따라말하기를 실시한 다른 연구에서는 두 집단의 수행이 비슷한 것 으로 나타났다(Stokes, Wong, Fletcher, \& Leonard, 2006). 이에 대 해 Stokes 등(2006)은 영어나 스웨덴어와는 다른 광둥어의 단순한 구조, 강세 패턴, 쉬운 발음 등의 언어적 특성이 수행에 영향을 미쳤 기 때문이라고 언급하였다. 이러한 연구결과는 언어마다 상이한 말 소리, 음소배열구조 및 규칙을 가지고 있으므로 음소배열확률이 언 어 기저의 처리 과정에 미치는 효과가 다를 수 있음을 예측하게 한 다. 특히 영어와 한국어는 음소목록이 서로 다르고, 한국어는 모음 만 음절핵이 될 수 있는 반면에 영어는 일부 자음도 음절핵이 될 수 있으며, 음절핵과 결합 가능한 자음의 수 등, 음운론, 형태론 측면에 서 완전히 다른 체계를 가진 언어이다(Shin \& Cha, 2003). 그러나 음소배열확률과 관련한 이전의 연구결과들은 대부분 영어권에서 수행된 것이며, 이에 따라 한국어권에서 음소배열확률이 어휘학습 능력과 음운기억 능력에 미치는 효과를 살펴볼 필요가 있다.

본 연구에서는 비단어 따라말하기와 빠른의미연결 과제에서 한 국어 비단어의 음소배열확률을 체계적으로 분석, 조작함으로써 한국어에서 단어유사성이 언어 기저의 처리 과정에 미치는 영향을 살펴보고자 하였다. 특히 본 연구에서는 위치별 단일 분절음의 배 열확률이 아닌 위치별 두음소배열확률(positional biphone probability)을 사용하였다. 이는 우리가 듣는 말소리가 단일 분절음 단위 가 아닌 음소 연쇄의 단위로 제시되며, 단일 분절음보다 두음소 연 쇄의 단위에 더 민감하기 때문이다(Coady \& Aslin, 2004). 즉, 청각 적으로 제시되는 비단어의 음운 정보 처리에 음소배열확률이 미치 는 영향을 살펴보기 위해서는 두음소배열확률이 더 적절하다는 것이다. 영어권에서는 오래 전부터 두음소배열확률과 관련하여 다 
양한 연구가 활발히 진행되어 왔다(Storkel, 2004; Storkel \& Hoover, 2010; Vitevitch \& Luce, 2004). 특히 다양한 연구들을 통해 개발된 음소배열확률 계산기들이 온라인에서 무료로 사용할 수 있도록 보 급되어 단어 내 특정위치에서 분절음(segment), 두음소(biphone) 및 삼음소(triphone) 배열확률값을 쉽게 산출할 수 있다. 그러나 한 국에는 아직까지 시중에 보급되어 사용할 수 있는 음소배열확률 계산기가 없으며, 한국어를 사용하는 성인과 아동의 발화를 수집 하여 두음소배열빈도를 구한 연구결과(Shin, 2005; 2008)가 있으나 발화 내의 모든 음절 내 또는 음절 경계의 위치에서 발생할 수 있는 빈도를 함께 산출한 것으로 단어 내의 위치별 두음소배열확률을 계산한 값이 아니다. 현재까지 국내에서 위치별 음소배열확률을 활용한 연구는 이중언어 아동들을 대상으로 한국어, 영어 비단어 변별 과제에서 두 언어의 병행활성화를 살펴본 Lee와 Storkel (2012) 의 논문 1 편이며, 한국어에서 위치별 두음소배열확률에 따른 음운 단기기억 능력, 어휘학습 능력을 살펴보고, 일반아동과 단순언어 장애 아동의 수행을 비교한 연구는 아직까지 실시된 바가 없다.

따라서 본 연구에서는 한국어의 위치별 두음소배열확률을 조정 하여 단어유사성이 음운 단기기억 능력과 어휘학습 능력에 미치는 영향을 알아보고자 (1) 만 4-6세의 학령전기의 일반아동, 단순언어 장애 아동을 대상으로 단어유사성에 따른 비단어 따라말하기와 빠른의미연결 과제의 수행 차이를 비교 및 분석하고, (2) 각 집단에 서 비단어 따라말하기와 빠른의미연결 산출 및 이해단계의 수행과 다양한 변인 간에 유의한 상관을 보이는지, (3) 각 집단에서 비단어 따라말하기와 빠른의미연결 이해 과제에서의 문항별 정반응률 평 균과 각 문항에서 비단어의 두음소배열확률 간에 유의한 상관을 보이는지 살펴보고자 하였다.

\section{연구방법}

\section{연구대상}

본 연구에는 서울 및 경기 지역에 거주하는 단순언어장애 아동 15 명(여아 7명, 남아 8명, 나이 4;2-6;9세)과 성별 및 연령을 일치시킨 만 4-6세의 일반아동 20 명(여아 10 명, 남아 10 명, 나이 4;3-6;9세), 총 35 명이 참여하였다. 단순언어장애 아동은 Leonard (2014)의 선정 기준에 근거하여 (1) Korean Kaufman Assessment Battery for Children (K-ABC; Moon, \& Byun, 2003)의 동작성 지능검사의 표준 점 수가 85점 이상, (2) 수용 및 표현어휘력검사(Receptive \& Expressive Vocabulary Test, REVT; Kim, Hong, Kim, Jang, \& Lee, 2009)에서 수용 및 표현어휘력 점수가 모두 아동의 연령 범위에서 - $1.25 \mathrm{SD}$ 미 만에 속하고, (3) 알버타 언어 및 발달 설문지(Alberta Language and
Development Questionnaire, ALDeQ; Paradis, Emmerzael, \& Duncan, 2010) 결과, $-1.25 \mathrm{SD}$ 이하에 있으며, (4) 아동의 부모 또는 교사 에 의해 발달 과정 중에 신체 및 감각, 인지, 정서, 행동과 관련된 특 별한 문제가 없는 것으로 보고된 아동으로 선정하였다.

일반아동은 (1) K-ABC (Moon \& Byun, 2003) 동작성 지능검사의 표준 점수가 85점 이상이며, (2) 수용 및 표현어휘력검사(REVT; Kim et al., 2009)에서 수용 및 표현어휘력 점수가 모두 아동의 연령 범위 에서 정상 범주(0 SD 이상)에 있고, (3) 알버타 언어 및 발달설문지 (ALDeQ; Paradis et al., 2010) 결과, 정상 범주(0 SD 이상)에 속하며, (4) 아동의 부모 또는 교사에 의해 신체 및 감각, 인지, 정서, 행동과 관련된 특별한 문제가 없는 것으로 보고된 아동으로 선정하였다.

일반아동의 평균 생활연령은 68.25 개월 $(\mathrm{SD}=9.5)$, 단순언어장애 아동의 평균 생활연령은 67.00 개월 $(\mathrm{SD}=9.8)$ 이었다. 일반아동의 동 작성 지능 평균은 108.55 점 $(\mathrm{SD}=5.2)$, 단순언어장애 아동의 동작성 지능 평균은 105.13 점 $(\mathrm{SD}=7.5)$ 이었다. 또한, 일반아동의 수용어휘력 은 72.80 점 $(\mathrm{SD}=10.0)$, 단순언어장애 아동의 수용어휘력은 52.00점 $(\mathrm{SD}=11.0)$ 이었으며, 일반아동의 표현어휘력은 78.00 점 $(\mathrm{SD}=10.8)$, 단순언어장애 아동의 표현어휘력은 53.00 점 $(\mathrm{SD}=11.5)$ 이었다.

비교 집단의 통제가 잘 이루어졌는지 확인하기 위해 독립표본 $t$ 검정을 실시한 결과, 두 집단의 생활연령 및 동작성 지능에 통계적 으로 유의한 차이가 나타나지 않았다 $(p>.05)$. 그러나 두 집단 간 수용 $\left(t_{(33)}=5.829, p<.001\right)$ 및 표현 어휘력 $\left(t_{(33)}=6.576, p<.001\right)$ 에 대한 차이가 통계적으로 유의한 것으로 나타났다. 본 연구에 참여 한 아동들의 생활연령, 동작성 지능, 수용 및 표현어휘력의 평균 및 표준편차는 Table 1과 같다.

\section{실험 과제 및 절차}

비단어 선정

본 연구의 비단어 따라말하기와 빠른의미연결 과제에서 사용된 비단어는 비단어 따라말하기와 관련한 선행연구(Hwang, 2015;

Table 1. Participants' characteristics

\begin{tabular}{lccc}
\hline Characteristic & $\begin{array}{c}\text { NL group } \\
(\mathrm{N}=20)\end{array}$ & $\begin{array}{c}\text { SLI group } \\
(\mathrm{N}=15)\end{array}$ & $t$ \\
\hline Age $(\mathrm{mo})$ & $68.25(9.5)$ & $67.00(9.8)$ & .382 \\
Nonverbal IO & $108.55(5.2)$ & $105.13(7.5)$ & 1.597 \\
Receptive vocabulary $^{\mathrm{b}}$ (raw score) & $72.80(10.0)$ & $52.00(11.0)$ & $5.829^{* * *}$ \\
Expressive vocabulary (raw score) & $78.00(10.8)$ & $53.00(11.5)$ & $6.576^{* * *}$ \\
\hline
\end{tabular}

Values are presented as mean (SD).

$\mathrm{NL}=$ children with normal language; $\mathrm{SLI}=$ children with specific language impairment. ${ }^{a}$ Korean Kaufman Assessment Battery for Children (Moon \& Byun, 2003), ${ }^{b}$ Receptive \& Expressive Vocabulary Test (Kim, Hong, Kim, Jang, \& Lee, 2009). ${ }^{* * *} p<.001$. 
Kim \& Ha, 2014; Lee et al., 2013)의 비단어 목록에서 임의로 선정 하였다. 선정한 비단어는 단어유사성이 높은 비단어 16 개, 단어유 사성이 낮은 비단어 16 개이며, 총 32 개의 비단어들의 단어유사성, 조음복잡성이 조정되어 실험 과제에서 사용되었다.

\section{비단어의 조음복잡성 조정}

조음복잡성은 단어유사성과 함께 비단어 따라말하기의 수행에 영향을 미치는 중요한 요인으로 여겨져 왔다(Gallon et al., 2007). 다른 연구에서도 조음복잡성이 높아질수록 산출의 어려움도 커져 일반아동과 단순언어장애 아동의 조음오류가 증가한다는 일관적 인 보고가 있다(Kim, Lee, Han, \& Lee, 2017; Marshall \& Van Der Lely, 2007). 따라서 본 연구에서는 조음의 어려움으로 산출이 제한 받는 것을 최대한 배제하고자 비단어 따라말하기와 빠른의미연결 과제에서 모든 비단어의 조음복잡성 점수를 5점 이하로 조정하였 다(Kim \& Ha, 2014). 조음복잡성 배점 기준은 Lee 등(2004)의 한 국어 조음복잡성 지표를 참고하였다. 배점 기준에 의하면 (1) 조음 위치적 측면에서 치경경구개음, 연구개음을 포함하는 경우, (2) 조 음방법적 측면에서 마찰음 또는 파찰음, 유음을 포함하는 경우, (3) 이중모음을 포함하는 경우, (4) 음절의 형태가 자음으로 끝나는 경 우, (5) 인접한 자음(예: $\mathrm{VC}+\mathrm{CV}$ )이 있는 경우, (6) 인접한 자음의 조 음위치가 다른 경우, (7) 3 음절 이상의 길이인 경우의 조건에서 1 점 씩 부과한다. 따라서 조음복잡성 점수를 조정하는 과정에서 일부 자음과 모음을 동일한 조음방법(예:/t/를 /k/) 또는 조음위치(예: /i/ 를 $/ \mathrm{e} /, \mathrm{i} /$ 를 $/ \mathrm{u} /)$ 의 음운 특성이 유사한 소리로 변경하거나 종성 자 음을 생략 또는 첨가하는 방식을 사용하였다.

\section{비단어의 단어유사성 조정}

비단어 따라말하기와 관련한 선행연구들은 실제 어휘들과 음운 배열구조가 유사한 단어유사성이 높은 비단어가 장기기억에서 비 슷한 음운배열의 단어들을 활성화시키고, 목표 비단어를 일시적으 로 저장 및 회상하는 데 도움을 받는다고 일관적으로 보고해왔다 (Baddeley, 2003; Edwards et al., 2004). 이처럼 영어권에서는 오래 전부터 단어유사성과 관련하여 활발한 연구가 진행되어 왔다. 단 어유사성을 조절하기 위한 방법으로 주관적 평정척도(Frisch et al., 2000; Gathercole, 1995; Saito, Yoshimura, Itakura, \& Ralph, 2003), 음소배열확률을 사용해 왔으며, 최근 주관적 평정척도를 사용한 연구보다 단어유사성의 정의에 부합하고, 정확한 수치로 나타나는 음소배열확률을 사용한 연구가 더 많아지고 있는 추세이다(Storkel, 2001; Tattersall, Nelson, \& Tyler, 2015). 본 연구에서는 비단어의 두 음소배열확률(biphone probability)을 조정함으로써 단어유사성이
높은 비단어와 낮은 비단어로 구성하고자 하였다. Hwang (2015)의 연구방법을 토대로 표준어를 사용하는 성인들의 발화에서 두음소 연쇄의 빈도를 조사한 Shin (2008)의 자료를 참고하였다. 즉, 목표 비단어를 구성하는 두음소 연쇄빈도의 절반 이상이 조사 자료의 상위 $40 \%$ 내의 소리로 구성된 경우에 두음소배열확률이 높은 단 어로 분류하였으며, 두음소 연쇄빈도의 절반 이상이 조사 자료의 하위 $50 \%$ 내의 소리로 구성된 경우에 두음소배열확률이 낮은 단 어로 분류하였다. 그러나 Shin (2008)의 조사 자료는 발화 내의 모 든 음절 내 또는 음절 경계의 위치에서 발생할 수 있는 두음소 연쇄 빈도만을 나타낸 것으로 단어 내의 위치별 두음소배열확률을 고려 한 값이 아니다. 따라서 선행연구(Lee \& Storkel, 2012)의 방법을 참 조하여 현대국어 사용빈도 조사 자료(National Institute of Korean Language, 2002)의 58,329개 단어를 기반으로 고안한 음소배열확 률 계산기를 사용하여, 위치별 두음소배열확률(positional biphone probability)을 계산하였다. 위치별 두음소배열확률을 계산하는 식 은 특정 위치에서 목표하는 두음소가 배열된 모든 단어의 수를 특 정 위치에서 두음소배열이 가능한 모든 단어의 수로 나누는 것이 다. 그리고 계산된 위치별 두음소배열확률 값들을 모두 합하여 해 당하는 비단어의 두음소배열확률을 산출할 수 있다(Vitevitch \& Luce, 2004). 예를 들면, [사상]이라는 단어의 두음소배열확률은 0.165117 로 / / 과// / / 가 결합할 확률 0.034722 와// /와/시이 결합 할 확률 $0.019882, /$ / 과 / / / 가 결합할 확률 $0.039186, / / /$ 와 / / / 이 결합할 확률 0.071327 이 모두 더해짐으로써 구해진다. 따라서 이러 한 방법으로 두음소배열확률이 구해진 총 32 개의 비단어들은 비 단어 따라말하기 과제에서 사용할 2-6음절의 단어유사성이 높은 비단어 10 개와 단어유사성이 낮은 비단어 10 개, 빠른의미연결 과제 에서 사용할 2-4음절의 단어유사성이 높은 비단어 6개와 단어유 사성이 낮은 비단어 6 개로 선택 및 분류되었다. 비단어 따라말하기 와 빠른의미연결의 비단어 목록과 두음소배열확률을 Appendix 1 에 제시하였다.

비단어 따라말하기와 빠른의미연결 과제에서 단어유사성이 높 은 비단어와 단어유사성이 낮은 비단어의 두음소배열확률 간의 통 계적으로 유의한 차이가 있는지 확인하고자 독립표본 $t$-검정을 실 시하였다. 그 결과, 비단어 따라말하기 $\left(t_{(18)}=-9.662, p<.001\right)$ 와 빠 른의미연결 $\left(t_{(10)}=-4.195 p<.01\right)$ 에서 모두 단어유사성이 높은 비단 어와 단어유사성이 낮은 비단어 간에 두음소배열확률의 유의한 차이가 있는 것으로 나타났다. 비단어 따라말하기와 빠른의미연결 과제에서 단어유사성이 높은 비단어와 단어유사성이 낮은 비단어 목록들의 두음소배열확률(biphone probability) 평균 및 표준편차 값은 Table 2와 같다. 
Table 2. Mean and variance of biphone probability for nonword repetition and fast mapping tasks

\begin{tabular}{|c|c|c|c|}
\hline & \multicolumn{2}{|c|}{ Wordlikeness } & \multirow{2}{*}{$t$} \\
\hline & High & Low & \\
\hline Nonword repetition & .0998 (.02323) & $.0229(.00973)$ & $-9.662^{* * *}$ \\
\hline Fast mapping & $.0915(.03993)$ & $.0206(.01113)$ & $-4.195^{* *}$ \\
\hline
\end{tabular}

Values are presented as mean (SD).

${ }^{* *} p<.01,{ }^{* * *} p<.001$.

\section{비단어 따라말하기 과제(Nonword repetition task)}

비단어 따라말하기 과제의 실시방법은 선행연구 과제(Lee et al., 2013)를 참고하여 제작하였다. 검사자는 아동에게 한국어가 모국 어인 여성 화자가 사전에 녹음한 비단어 음성 파일을 헤드폰을 통 해 들려주고 즉각적으로 따라 말하도록 지시하였다. 비단어 문항 은 2음절부터 6음절까지 음절 길이 순으로 제시되며, 각 음절 길이 당 단어유사성이 높은 비단어 2 개와 단어유사성이 낮은 비단어 2 개로 구성되어 있다. 순서 효과를 방지하기 위해 각 음절 길이 내에 서는 임의의 순서로 제시되었다. 비단어 문항 간 제시 간격은 이전 문항의 비단어를 듣고 따라 말한 후 다음 문항의 비단어를 듣기까 지 준비 과정에 충분한 시간을 제공하기 위해 5초의 심(pause)을 두 었다. 모든 문항은 한 번씩만 들려주었으나 주변 상황(예: 소음)에 방해가 있었거나 아동이 직접적으로 다시 한 번 들려줄 것을 요청 한 경우에 한해 한 번의 기회를 더 제공받았다. 과제를 시작하기 전 검사자는 과제에 대한 간단한 설명을 제공하였으며(예: “지금부터 이상한 말을 들려줄 거에요. 한 번씩만 들려줄 수 있으니 잘 듣고 들 은 소리를 그대로 따라 말해주세요”), 연습 문항을 통해 아동이 제 대로 이해하였는지 점검한 후에 본 검사를 실시하였다. 검사가 시 작된 후에는 검사자는 아동의 반응에 대해 어떠한 피드백도 제공 하지 않았다. 아동의 모든 반응은 녹음기로 녹음되는 동시에 검사 자에 의해 기록지에 전사되었다. 그리고 검사가 종료된 후에는 녹 음된 아동의 음성을 다시 한 번 들으며, 전사된 기록이 맞는지 검토 하였다.

비단어 따라말하기 과제의 점수 산정 방법은 크게 3 가지로 항목, 음절, 음소 단위의 채점이 있는데, 영어권에서는 주로 항목 단위 (Chiat \& Roy, 2007; Weismer et al., 2013)와 음소 단위(Dollaghan \& Campbell, 1998)를 사용해 왔으며, 한국어에서는 주로 음절 단위 (Lee et al., 2013; Yim, Kim, \& Yang, 2015), 음소 단위(Hong \& Yim, 2014; Lee, 2015)를 사용해 왔다. 일부 연구에서는 아동의 오류유형 에 대한 특성을 조사하기 위한 채점 방식으로 음절(Lee et al., 2013) 및 음소(Kim \& Ha, 2014) 단위가 적절하며, 일반아동과 단순언어 장애 아동을 선별하기 위한 채점 방식으로 항목 단위가 더 적합할
수 있다고 보고하였다(Roy \& Chiat, 2004). 이는, 비단어 따라말하 기에서 일반아동과 단순언어장애 아동의 수행에 미치는 영향이 채 점 방식에 따라 달라질 수 있으며, 연구의 목적에 맞는 채점 방식의 필요성을 나타낸다. 본 연구에서는 비단어 따라말하기의 채점 방식 으로 항목 단위를 사용하였으며, 비단어 문항을 완전히 정확하게 따라 말한 경우 정반응한 것으로 간주하여 항목당 1 점을 부과하였 다. 또한, 특정 음소의 생략, 대치, 첨가 오류를 제외한 경미한 왜곡 은 정반응한 것으로 간주하였다. 아동이 정정하여 다시 말하는 경 우에는 최종적으로 수정된 반응을 아동의 반응으로 간주하였다. 획득된 항목 점수는 총 문항수로 나눈 후 100 을 곱하여 정반응률 (\%)로 재산출하였다.

\section{빠른의미연결 과제(Fast mapping task)}

빠른의미연결 과제는 선행연구(Kan, Sadagopan, Janich, \& Andrade, 2014)의 방법을 참고하여 제작하였으며, 어린 아동들의 인 지적 부담을 줄여주기 위해 학습할 비단어의 총 개수와 제시 간격 등을 조정하였다. 빠른의미연결에서 사용된 그림 자극은 Horst와 Hout (2016)에서 Novel Object \& Unusual Name (NOUN)의 64개 의 새로운 모형(novel object) 중 familiarity value $(F)$ 가 하위 $25 \%$ 이하인 28 개의 모형 중에서 12 개를 임의로 선택하였다. 그리고 선 택된 그림 자극들을 12 개의 비단어와 각각 짝을 지어 12 쌍의 목록 으로 구성하였다. 빠른의미연결 과제의 그림 자극과 $F$ 값을 Appen$\operatorname{dix} 2$ 에 제시하였다.

빠른의미연결 과제의 문항은 2-4음절의 비단어로 구성되어 있다. 각 음절 길이에서 단어유사성이 높은 비단어 2 개와 단어유사성이 낮은 비단어 2 개가 한 세트로 구성되며, 각 아동은 음절 길이가 짧 은 2음절부터 4 음절까지 차례대로 총 3세트의 비단어를 학습하게 된다. 빠른의미연결의 학습 단계는 제시 단계(presentation phase)와 측정 단계(probing phase)로 이루어져 있으며, 제시 단계가 측정 단 계를 선행한다. 예를 들면, 한 세트의 비단어의 제시 단계에 이어 측 정 단계까지 마친 후 바로 다음 세트의 비단어의 제시 단계와 측정 단계가 시작되는 것이다. 제시 단계에서는 노트북 화면에 그림 자 극이 6초간 보여지는 동안 그림 자극과 짝을 이룬 비단어를 녹음된 음성파일로 2 번씩 들려준다. 6초가 지나면 화면이 2초간 검은색 바 탕으로 전환되었다가 다음 화면의 그림 자극으로 넘어간다. 4 쌍의 비단어와 그림 자극으로 구성된 한 세트의 제시 단계가 끝나면, 10 초간의 심(pause)을 가진 후 제시 단계에서 습득한 비단어를 측정 하는 단계(probing phase)가 이어진다. 측정 단계는 산출 측정(production probes)과 이해 측정(comprehension probes) 단계로 구성 되어 있으며, 산출 단계부터 시작한다. 산출 단계는 제시 단계에서 
보여준 4 개의 그림 자극이 화면에 하나씩 나타나는데, 아동은 그림 자극과 함께 제공되었던 비단어를 기억하여 명명(naming)해야 한 다. 산출 단계가 끝난 직후에는 이해 단계가 시작된다. 한 화면에 제 시 단계에서 보여준 4 개의 그림 자극이 동시에 제시되며, 비단어의 녹음된 음성파일을 듣고 해당하는 그림 자극을 선택하여야 한다. 한 세트당 총 4 번의 기회가 주어지는데, 그림 자극의 배열이 매 화 면 변경되도록 설정함으로써 목표 자극을 선택하는 확률을 .25 로 조정하였다. 또한, 제시 단계와 산출 측정 단계에서도 순서 효과를 방지하기 위하여 모든 비단어를 임의의 순서로 제시하였다. 과제를 시작하기 전에 검사자는 아동에게 수행방법과 관련하여 간단한 설 명을 제공하였으며, 최대한 많은 수의 그림 자극과 비단어를 기억 하도록 지시하였다. 검사가 시작된 이후에는 아동의 반응에 대한 어떠한 긍정적, 부정적 피드백을 제공하지 않았다. 아동의 모든 반 응은 녹음 및 전사되었으며, 검사가 종료된 후에는 녹음된 아동의 음성과 검사자의 기록이 맞는지 검토하였다.

빠른의미연결의 산출 단계에서는 음소 단위의 채점 방식을 사용 하였다. 이는 선행연구의 산출 측정 단계에서 바닥 효과로 줄어든 음소배열확률의 효과가 감소하는 것(Storkel, 2001)과 단순언어장 애 아동과 일반아동의 간 유의한 차이를 보이지 않았던 것을 방지 하고자 함이다(Gray, 2006). 따라서 아동이 정조음한 음소에 1점씩 부과하였으며, 대상자가 모른다고 응답하거나 8초 이상 무응답인 경우에 오반응한 것으로 간주하여 0 점으로 채점하였다. 빠른의미 연결의 이해 단계에서는 아동이 비단어에 해당하는 그림 자극을 정확히 가리킨 경우에만 맞은 것으로 간주하여 1 점을 주었으며, 대 상자가 모른다고 하거나 무응답인 경우 오반응한 것으로 간주하여 0 점으로 채점하였다. 최종적으로 획득한 산출 및 이해 점수는 모두 정반응률(\%)로 재산출하였다.

\section{실험 절차}

모든 검사는 소음이 없는 조용한 장소에서 연구자와 아동이 일 대일로 진행하였다. 실험 순서는 먼저 선별검사로 수용-표현어휘력 검사(REVT; Kim et al., 2009)와 카우프만 아동용 지능 검사(K$\mathrm{ABC}$; Moon \& Byun, 2003)의 동작성 하위검사를 수행하였으며, 실험집단의 선정 기준을 충족한 아동들에 한해 실험 과제인 비단 어 따라말하기와 빠른의미연결을 실시하였다. 모든 실험을 완료하 기까지 1 시간 30 분 정도의 시간이 소요되었다.

\section{자료의 통계적 처리}

단어유사성에 따른 비단어 따라말하기와 빠른의미연결의 이해 및 산출 단계에서 집단 간 수행의 차이를 보이는지 알아보기 위해
집단 간 요인을 두 집단(일반아동, 단순언어장애 아동)으로 놓고, 집단 내 요인을 단어유사성(고, 저)으로 설정하여 $2 \times 2$ 이원혼합 분산분석(two-way mixed ANOVA)을 실시하였다. 또한, 두 집단의 비단어 따라말하기와 빠른의미연결의 이해 및 산출 단계에서의 수 행과 다양한 변인 간의 상관관계, 각 실험 과제에서 두 집단의 비단 어 문항별 평균점수와각 비단어의 음소배열확률 간에 상관관계를 살펴보기 위하여 Pearson 적률상관계수를 산출하였다. 모든 자료 는 SPSS version 20 (IBM, Armonk, NY, USA)를 사용하여 통계적 분석을 실시하였다.

\section{신뢰도}

비단어 따라말하기와 빠른의미연결의 이해 및 산출 측정 단계의 수행에 대한 평가자 간 신뢰도는 전체 대상 아동의 $20 \%$ 에 해당하 는 일반아동 4 명, 단일언어발달지연 아동 3 명의 자료를 임의로 추 출하여 산출하였다. 아동의 음성의 재전사 및 분석은 주 연구자인 제 1 평가자 1 인과 언어병리학석사 졸업생인 제 2 평가자 1 인에 의해 이루어졌다. 평가자 간 신뢰도의 산출은 제 1 평가자와 제 2 평가자가 채점한 결과에서 서로 일치한 문항수를 전체 문항수로 나누고 100 을 곱하여 산출하였다. 그 결과, 비단어 따라말하기의 평가자 간 신 뢰도는 $93.5 \%$, 빠른의미연결의 평가자 간 신뢰도는 이해가 $100 \%$, 산출이 $92.5 \%$ 로 나타났다.

\section{연구결과}

\section{집단 간 단어유사성에 따른 비단어 따라말하기 과제의 수행 차이}

두 집단(일반아동, 단순언어장애 아동) 간 단어유사성(고, 저)에 따른 비단어 따라말하기 정반응률의 평균과 표준편차에 대한 기술 통계는 Table 3과 같다.

두 집단의 기술통계 결과가 통계적으로 유의한지 알아보기 위해 집단 $(2) \times$ 단어유사성(2)의 이원혼합분산분석(two-way mixed $\mathrm{ANOVA})$ 을 실시한 결과는 다음과 같다. 집단의 주효과가 유의하 였다 $\left(F_{(1,33)}=26.869, p<.001\right)$. 즉, 비단어 따라말하기에서 단순언어

Table 3. Descriptive statistics of nonword repetition scores (\%) by subgroup

\begin{tabular}{lccc}
\hline & \multicolumn{3}{c}{ Wordlikeness } \\
\cline { 2 - 4 } & High & Low & Total \\
\hline NL group (N=20) & $57.00(15.9)$ & $19.05(13.2)$ & $38.25(14.5)$ \\
SLl group (N=15) & $30.67(20.5)$ & $3.33(4.9)$ & $17.00(12.7)$ \\
\hline
\end{tabular}

Values are presented as mean (SD).

$\mathrm{NL}=$ children with normal language; $\mathrm{SLI}=$ children with specific language impairment. 
장애 아동 $(\mathrm{M}=17.00, \mathrm{SD}=12.7)$ 의 수행력이 일반아동 $(\mathrm{M}=38.25$, $\mathrm{SD}=14.5)$ 에 비해 유의하게 낮았다. 또한, 단어유사성의 주효과도 유의하였다 $\left(F_{(1,33)}=122.974, p<.001\right)$. 즉, 비단어 따라말하기에서 단어유사성이 높은 비단어 $(\mathrm{M}=43.83, \mathrm{SD}=18.2)$ 의 수행력이 낮은 비단어 $(\mathrm{M}=11.42, \mathrm{SD}=9.0)$ 에 비해 유의하게 높았다. 그러나 단어 유사성과 집단의 이차 상호작용이 통계적으로 유의하지 않았다 $\left(F_{(1,33)}=3.024, p>.05\right)$. 비단어 따라말하기에 대한 일반아동과 단순 언어장애 아동의 수행도는 Figure 1과 같다.

\section{집단 간 단어유사성에 따른 빠른의미연결 이해 단계의 수행 차이}

두 집단(일반아동, 단순언어장애 아동) 간 단어유사성(고, 저)에 따른 빠른의미연결 이해 단계의 정반응률의 평균과 표준편차에 대 한 기술통계는 Table 4 와 같다.

두 집단의 기술통계 결과가 통계적으로 유의한지 알아보기 위해 집단(2) $\times$ 단어유사성(2)의 이원혼합분산분석(two-way mixed ANOVA)을 실시한 결과는 다음과 같다. 집단의 주효과가 유의하였다 $\left(F_{(1,33)}=40.967, p<.001\right)$. 즉, 빠른의미연결의 이해 단계에서 단순언 어장애 아동 $(\mathrm{M}=32.78, \mathrm{SD}=14.7)$ 의 수행력이 일반아동 $(\mathrm{M}=58.33$, $\mathrm{SD}=16.6)$ 에 비해 유의하게 낮았다. 또한, 단어유사성의 주효과도

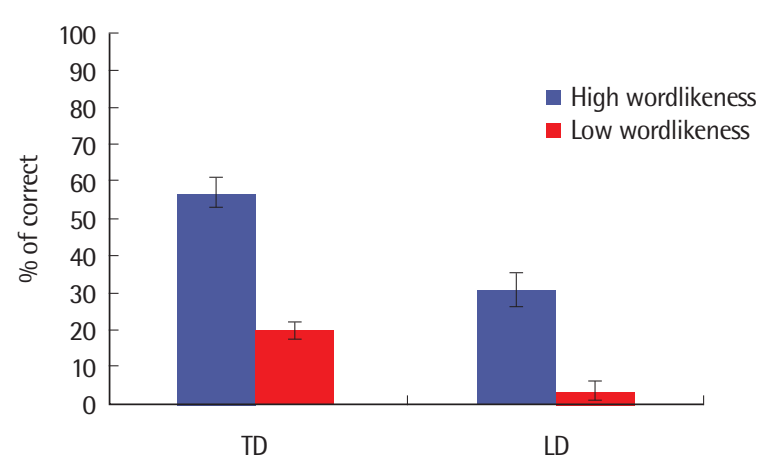

Figure 1. Nonword repetition task scores (\%) by group and wordlikeness. $\mathrm{NL}=$ children with normal language; $\mathrm{SLI}=$ children with specific language impairment.

Table 4. Descriptive statistics of comprehension scores (\%) of fast mapping task by subgroup

\begin{tabular}{lccc}
\hline & \multicolumn{3}{c}{ Wordlikeness } \\
\cline { 2 - 4 } & High & Low & Total \\
\hline NL group (N=20) & $67.50(18.3)$ & $49.17(14.8)$ & $58.33(16.6)$ \\
SLI group (N=15) & $46.67(16.9)$ & $18.89(12.4)$ & $32.78(14.7)$ \\
\hline
\end{tabular}

Values are presented as mean (SD).

$\mathrm{NL}=$ children with normal language; $S L I=$ children with specific language impairment.
유의하였다 $\left(F_{(1,33)}=39.271, p<.001\right)$. 즉, 빠른의미연결의 이해 단계 에서 단어유사성이 높은 비단어( $\mathrm{M}=57.08, \mathrm{SD}=17.6)$ 의 수행력이 낮은 비단어( $\mathrm{M}=34.03, \mathrm{SD}=13.6)$ 에 비해 유의하게 높았다. 단어유 사성과 집단의 이차상호작용은 통계적으로 유의하지 않았다 $\left(F_{(1,33)}=\right.$ $1.647, p>.05)$. 빠른의미연결 이해 단계에 대한 일반아동과 단순언 어장애 아동의 수행도는 Figure 2 와 같다.

\section{집단 간 단어유사성에 따른 빠른의미연결 산출 단계의 수행 차이}

두 집단(일반아동, 단순언어장애 아동) 간 단어유사성(고, 저)에 따른 빠른의미연결 산출 단계의 정반응률의 평균과 표준편차에 대 한 기술통계는 Table 5 와 같다.

두 집단의 기술통계 결과가 통계적으로 유의한지 알아보기 위해 집단 $(2) \times$ 단어유사성(2)의 이원혼합분산분석(two-way mixed $\mathrm{ANOVA)}$ 을 실시한 결과는 다음과 같다. 집단의 주효과가 유의하 였다 $\left(F_{(1,33)}=4.270, p<.05\right)$. 즉, 빠른의미연결의 산출 단계에서 단순 언어장애아동( $\mathrm{M}=10.86, \mathrm{SD}=11.3)$ 의 수행력이 일반아동( $\mathrm{M}=17.11$, $\mathrm{SD}=13.0)$ 에 비해 유의하게 낮았다. 그러나 단어유사성의 주효과 $\left(F_{(1,33)}=.234, p>.05\right)$, 단어유사성과 집단의 이차 상호작용이 통계 적으로 유의하지 않은 것으로 나타났다 $\left(F_{(1,33)}=.181, p>.05\right)$. 빠른

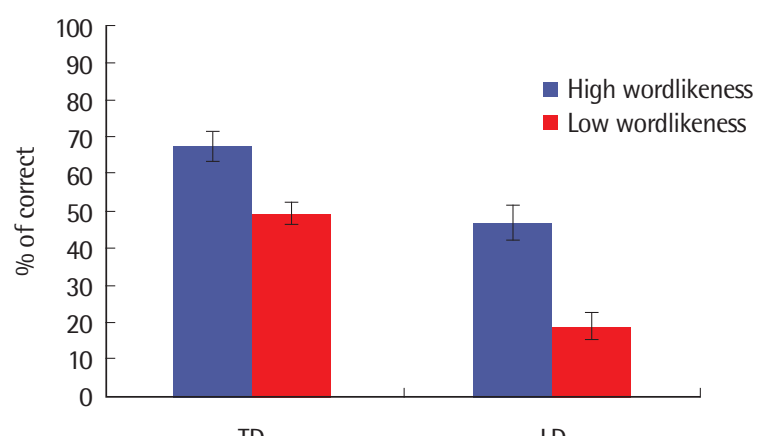

Figure 2. Comprehension scores (\%) of fast mapping task by group and wordlikeness.

$\mathrm{NL}=$ children with normal language; $\mathrm{SLI}=$ children with specific language impairment.

Table 5. Descriptive statistics of production scores (\%) of fast mapping task by subgroup

\begin{tabular}{lccc}
\hline & \multicolumn{3}{c}{ Wordlikeness } \\
\cline { 2 - 4 } & High & Low & Total \\
\hline NL group $(\mathrm{N}=20)$ & $17.20(13.7)$ & $17.02(12.2)$ & $17.11(13.0)$ \\
SLI group $(\mathrm{N}=15)$ & $12.20(13.0)$ & $9.52(9.5)$ & $10.86(11.3)$ \\
\hline
\end{tabular}

Values are presented as mean (SD).

$\mathrm{NL}=$ children with normal language; $\mathrm{SLI}=$ children with specific language impairment. 
의미연결의 산출 단계에 대한 일반아동과 단순언어장애 아동의 수 행도는 Figure 3과 같다.

\section{실험 과제에서 두 집단의 수행과 다양한 변인 간의 상관관계}

두 집단의 비단어 따라말하기와 빠른의미연결 이해 및 산출 단 계에서의 정반응률과 다양한 변인(연령, 수용 및 표현어휘력) 간의 유의한 상관관계가 있는지 살펴보고자 Pearson 상관계수를 산출

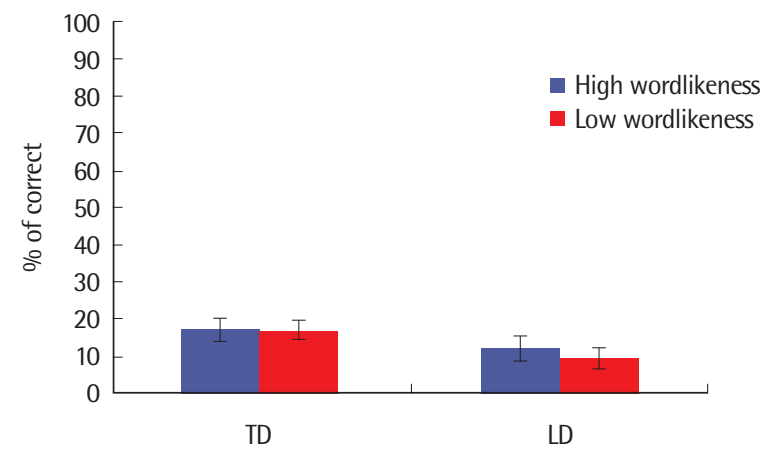

Figure 3. Production scores (\%) of fast mapping task by group and wordlikeness.

$\mathrm{NL}=$ children with normal language; $\mathrm{SLI}=$ children with specific language impairment.
하였다. 그 결과, 일반아동 집단은 비단어 따라말하기와 빠른의미 연결 이해 및 산출 단계에서의 정반응률과 다양한 변인(연령, 표현 및 수용어휘력) 간의 유의한 상관이 없는 것으로 나타났다( $p>.05)$. 단순언어장애 아동 집단은 빠른의미연결 이해 및 산출 단계에서의 정반응률과 다양한 변인 간에는 유의한 상관이 없는 것으로 나타났 다 $p>.05)$, 그러나 비단어 따라말하기에서의 정반응률과 수용 어휘 력 $(r=.864, p<.01)$ 간에 매우 높은 정적 상관, 표현 어휘력 $(r=.693$, $p<.01)$ 간에 높은 정적 상관을 보이는 것으로 나타났으며, 연령 $(r=$ $.594, p<.05)$ 간에도 유의한 정적 상관이 있는 것으로 나타났다. 두 집단의 실험 과제와다양한 변인 간의 상관계수는 Tables 6, 7과 같다.

\section{실험 과제에서 두 집단의 수행과 각 비단어의 두음소배열확률 간의 상관관계}

비단어 따라말하기에서 두 집단의 비단어 문항별 정반응률 평균 점수와 각 비단어의 두음소배열확률 간 상관관계

일반아동 집단 $(r=.704)$ 과 단순언어장애 아동 집단 $(r=.640)$ 에 서 비단어 문항별 정반응률 평균 점수와 각 비단어의 두음소배열 확률이 높은 정적 상관을 보이며, 통계적으로 유의한 것으로 나타 났다 $(p<.01)$. 이에 대한 상관분석 결과를 Tables 8 , 9에 제시하였으 며, 산포도를 Figure 4에 제시하였다.

Table 6. Correlation coefficient among tasks in children with typical language development

\begin{tabular}{lccccc}
\hline & $\begin{array}{c}\text { Expressive } \\
\text { vocabulary }\end{array}$ & $\begin{array}{c}\text { Receptive } \\
\text { vocabulary }\end{array}$ & $\begin{array}{c}\text { Nonword } \\
\text { repetition }\end{array}$ & $\begin{array}{c}\text { Fast mapping } \\
\text { production }\end{array}$ & $\begin{array}{c}\text { Fast mapping } \\
\text { comprehension }\end{array}$ \\
\hline Age in months & $.689^{* *}$ & $.821^{* * *}$ & .077 & .389 & .101 \\
Expressive vocabulary & - & $.821^{* * *}$ & .248 & .292 & .115 \\
Receptive vocabulary & - & - & .134 & .260 & .121 \\
Nonword repetition & - & - & - & -261 & -.072 \\
Fast mapping production & - & - & - & - & -215 \\
Fast mapping comprehension & - & - & - & - \\
\hline
\end{tabular}

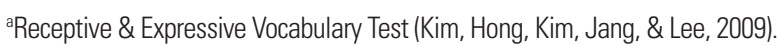

${ }^{* *} p<.01,{ }^{* * *} p<.001$.

Table 7. Correlation coefficient among tasks in children with language delay

\begin{tabular}{lccccc}
\hline & $\begin{array}{c}\text { Expressive } \\
\text { vocabulary }^{2}\end{array}$ & $\begin{array}{c}\text { Receptive } \\
\text { vocabulary }\end{array}$ & $\begin{array}{c}\text { Nonword } \\
\text { repetition }\end{array}$ & $\begin{array}{c}\text { Fast mapping } \\
\text { production }\end{array}$ & $\begin{array}{c}\text { Fast mapping } \\
\text { comprehension }\end{array}$ \\
\hline Age in months & $.926^{* * *}$ & $.829^{* * *}$ & $.594^{*}$ & .121 & .235 \\
Expressive vocabulary $^{2}$ & - & $.840^{* * *}$ & $-693^{* *}$ & .017 & .097 \\
Receptive vocabulary $^{\mathrm{a}}$ & - & - & $.864^{* * *}$ & .115 & .061 \\
Nonword repetition & - & - & - & -288 & -.022 \\
Fast mapping production & - & - & - & - & -178 \\
Fast mapping comprehension & - & - & - & - \\
\hline
\end{tabular}

${ }^{a}$ Receptive \& Expressive Vocabulary Test (Kim, Hong, Kim, Jang, \& Lee, 2009).

${ }^{*} p<.05,{ }^{* *} p<.01,{ }^{* * *} p<.001$. 
Kyeongran Bae, et al. - The Effect of Linguistic Knowledge and Korean Phonotactic Probability

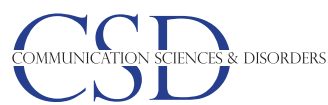

Table 8. Correlation coefficient between average score per nonword repetition stimuli and biphone probability of nonword in children with $\mathrm{NL}$

\begin{tabular}{lc}
\hline & Average score per stimuli in children with NL \\
\hline Biphone probability of nonword & $.704^{* *}$ \\
\hline
\end{tabular}

$\mathrm{NL}=$ children with normal language.

${ }^{* *} p<.01$.

Table 9. Correlation coefficient between average score per nonword repetition stimuli and biphone probability of nonword in children with SLI

\begin{tabular}{lc}
\hline & Average score per stimuli in children with SLI \\
\hline Biphone probability of nonword & $.640^{* *}$ \\
\hline
\end{tabular}

$S L I=$ children with specific language impairment.

${ }^{* *} p<.01$.

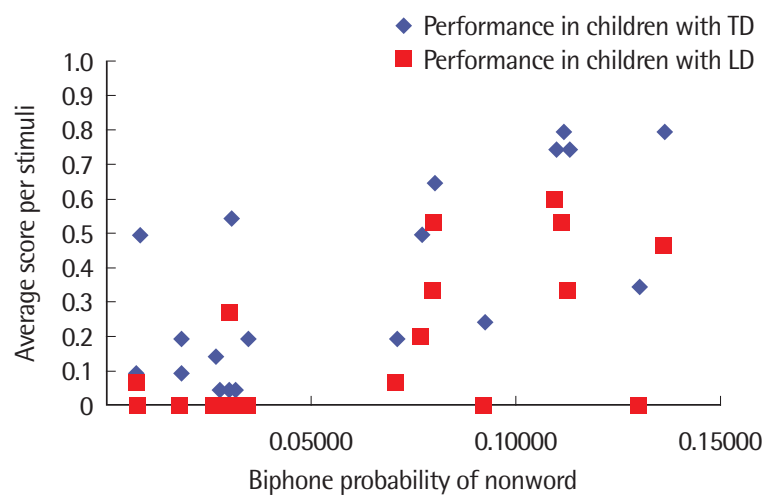

Figure 4. Scatter plot of average score per nonword stimuli and biphone probability of nonword in children with NL and SLI.

$\mathrm{NL}=$ children with normal language; $\mathrm{SLI}=$ children with specific language impairment.

\section{빠른의미연결의 이해 단계에서 두 집단의 비단어 문항별}

정반응률 평균 점수와 각 비단어의 두음소배열확률 간 상관관계

일반아동 집단에서 비단어 문항별 정반응률 평균 점수와각 비단 어의 두음소배열확률 간에 유의한 상관을 보이지 않았다( $p>.05)$ 단순언어장애 아동 집단에서는 비단어 문항별 정반응률 평균 점 수와 각 비단어의 두음소배열확률이 유의한 정적 상관을 보이는 것으로 나타났다 $(r=.589, p<.05)$. 이에 대한 상관분석 결과를 $\mathrm{Ta}-$ bles 10,11 에 제시하였으며, 산포도를 Figure 5에 제시하였다.

\section{논의 및 결론}

연구 결과, 비단어 따라말하기 과제에서 단순언어장애 아동의 수행이 일반아동의 수행에 비해 유의하게 낮았다. 이는 음운기억 용량의 제한(Dollaghan \& Campbell, 1998) 등으로 손상된 기저의 처리 기제를 가진 단순언어장애 아동이 일반아동에 비해 들은 정
Table 10. Correlation coefficient between average score per fast mapping stimuli and biphone probability of nonword in children with $\mathrm{NL}$

\begin{tabular}{lc}
\hline & Average score per stimuli in children with NL \\
\hline Biphone probability of nonword & .522 \\
\hline
\end{tabular}

$\mathrm{NL}=$ children with normal language

Table 11. Correlation coefficient between average score per fast mapping stimuli and biphone probability of nonword in children with SLI

\begin{tabular}{l}
\hline \multicolumn{1}{c}{ Average score per stimuli in children with SLI } \\
\hline Biphone probability of nonword \\
\hline SLI $=$ children with specific language impairment. \\
${ }^{*} p<.05$.
\end{tabular}

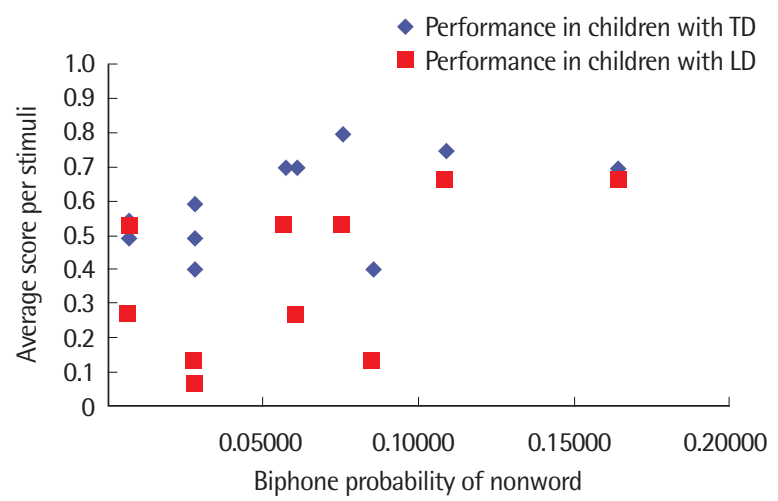

Figure 5. Scatter plot of average score per nonword stimuli and biphone probability of nonword in children with NL and SLI.

$\mathrm{NL}=$ children with normal language; $\mathrm{SLI}=$ children with specific language impairment.

보를 즉각적으로 따라말하는 데 더 낮은 수행을 보였던 선행연구 의 결과와 일치한다(Weismer et al., 2000). 단어유사성 측면에서는 단어유사성이 높은 비단어에서 수행이 단어유사성이 낮은 비단어 보다 유의하게 높았다. 이는 단일언어를 사용하는 성인(Vitevitch et al., 1997)과 일반아동(Van Bon \& Van Der Pijl, 1997; Zamuner, 2009)을 대상으로 한 비단어 따라말하기에서 단어유사성이 높은 비단어의 이점을 밝힌 결과들과 일치한다. 또한, 새로운 단어의 음 운 정보를 음운 기억장치에 일시적으로 저장하는 과정에서 단어유 사성이 높을수록 해당하는 언어에서 비슷한 음운 배열의 어휘가 많아져 어휘지식의 도움을 받기 용이하므로(Gathercole et al., 1991; Gathercole, 1995), 더 효율적으로 말소리 지각(Jusczyk \& Luce, 1994), 음운적 표상의 확립 및 저장(Munson, 2001)을 가능케 한다 는 이전 연구들의 주장을 지지한다. 이와 유사한 결과는 이중언어 를 사용하는 아동들을 대상으로 한 연구에서도 살펴볼 수 있다. Messer, Leseman, Boom과 Mayo (2010)에서는 만 4세의 네덜란드 
어 단일언어 일반아동과 터키어-네덜란드어 이중언어 일반아동을 대상으로 터키어와 네덜란드어에서 음소배열확률을 조절한 비단 어 따라말하기를 실시하였다. 연구 결과, 두 집단 모두 습득한 언어 의 비단어 따라말하기에서 음소배열확률의 효과를 나타냈다. 이 는, 단일언어 아동뿐만이 아니라 두 언어를 습득하는 이중언어 아 동 역시 언어학습의 경험으로 습득된 어휘지식이 음운정보 처리에 영향을 주었다는 사실을 나타낸다. 한편, 단어유사성과 집단의 상 호작용효과는 나타나지 않았는데, 이는 비단어 따라말하기 수행에 서 단순언어장애 아동의 음소배열효과를 나타낸 Munson, Kurtz 등(2005)의 연구결과와 일치하는 결과라 할 수 있다. 즉, 본 연구의 결과에서 단순언어장애 아동이 음운기억용량의 결함(Dollaghan \& Campbell, 1998; Weismer et al., 2000)과 어휘 부족(Gathercole \& Baddeley, 1990a) 등으로 인한 취약한 음운정보 처리 능력으로 단어유사성의 두 조건의 비단어 따라말하기 수행에서 일반아동에 비해 더 낮은 수행을 보였으나 단순언어장애 아동 또한 언어적 지식 의 도움을 받아 일반아동과 같이 단어유사성의 효과를 보임으로서 두 집단 간 수행의 차이가 유의하지 않았던 것으로 해석할 수 있다.

빠른의미연결 과제의 수행을 분석한 결과, 이해 단계에서 단순언 어장애 아동이 일반아동에 비해 유의하게 낮은 수행을 보였다. 이 는 단순언어장애 아동이 음운적 표상과 의미적 표상을 연결하는 것이 가능하지만 표상 간의 연결을 안정적으로 유지하는 능력의 손상으로 일반아동에 비해 더 낮은 수행을 보인다고 주장한 선행 연구(Alt et al., 2004; Gray, 2004)의 결과와 일치한다. 단어유사성 측면에서는 단어유사성이 높은 비단어에서 수행이 단어유사성이 낮은 비단어보다 유의하게 높은 것으로 나타났다. 이는 단어유사 성이 높은 비단어의 의미적 및 음운적 표상을 처리하는 과정에서 어휘집 내에 비슷한 음운배열구조의 단어들이 활성화되어 도움을 받는다는 선행연구(Storkel, 2001)의 입장과 일치한다. 이러한 단어 유사성의 효과는 두 언어를 습득하는 이중언어 아동을 대상으로 한 빠른의미연결의 수행에서도 살펴볼 수 있다. Alt, Meyers와 Figueroa (2013)는 4-5세의 학령전기와 7-8세의 학령기의 영어 단일언 어 아동, 스페인어-영어 이중언어 아동 집단에게 음소배열확률을 조정한 영어 빠른의미연결 과제를 실시하였다. 연구 결과, 두 집단 모두 음소배열확률이 낮은 비단어에 비해 음소배열확률이 높은 비 단어의 이해에서 더 높은 수행을 보였으며, 학령전기 아동에 비해 학령기 아동이 유의하게 높은 수행을 보이는 것으로 나타났다. 이 는 이미 습득한 어휘지식이 새로운 단어의 습득에 중요한 역할을 한다는 것을 나타내며, 앞서 단일언어 아동들을 대상으로 어휘 지 식이 새로운 단어의 표상을 형성하고 연결하는 데 중요한 영향을 미 치는 것을 밝힌 선행연구 결과들을 더욱 공고히 한다고 볼 수 있다.
단어유사성과 집단의 상호작용은 유의하지 않은 것으로 나타났는 데, 이는 단어유사성의 두 조건에서 일반아동과 단순언어장애 아 동의 수행 차이가 비슷하였음을 나타낸다. 선행연구에서는 어휘적 결함(Nash \& Donaldson, 2005), 음운기억용량의 제한(Gray, 2003a, 2003b; Jackson et al., 2016), 음운적 특성의 민감성 결여(Alt \& Plante, 2006; MacRoy-Higgins et al., 2013) 등의 요인을 단순언어장애 아동이 단어학습에서 낮은 수행을 보이는 기저의 원인으로 보았으 며, 이로 인해 음운적 및 의미적 표상을 형성하고 저장하는 데 어려 움을 보일 수 있다고 언급했다. 그러나 이러한 선행연구 결과는 일 반아동에 비해 단순언어장애 아동의 더 낮은 수행을 설명할 수 있 지만 본 연구에서 단어유사성에 따른 두 집단의 차이가 유의하지 않았던 것을 설명하지 못한다. 본 연구의 빠른의미연결의 이해 단 계에서 단순언어장애 아동이 단어유사성이 높은 비단어에서 더 높은 수행을 보인 것은 단어의 회상에서 단어유사성의 효과를 나 타낸 선행연구(Coady, Mainela-Arnold, \& Evans, 2013)와 같은 맥 락에서 설명될 수 있다. 즉, 새로운 어휘를 이해하기 위하여 표상을 처리하는데 단순언어장애 아동이 일반아동에 비해 효율이 낮을 수 있지만, 단순언어장애 아동도 선행지식의 영향을 받아 단어유 사성이 높은 단어의 이해에서 일반아동과 유사한 단어유사성의 효과를 보이고 있음을 의미한다.

빠른의미연결의 산출 단계에서 일반아동에 비해 단순언어장애 아동의 수행이 유의하게 낮았다. 이는 단순언어장애 아동이 새로 운 단어의 음운적 표상을 형성하고 유지하는 데 결함을 보였던 선 행연구의 결과들과 일치한다(Dollaghan, 1987; Edwards \& Lahey, 1998; Jackson et al., 2016). 한편, 빠른의미연결의 산출에서 단어유 사성의 효과에 관하여 일부의 연구에서는 약하지만 단어유사성이 높은 단어에서 이점을 보고하였으나(Storkel, 2001) 몇몇의 연구에 서는 낮은 점수로 단어유사성의 효과를 보이지 않는다는 상반된 결과를 보고하였다(Storkel \& Lee, 2011). 본 연구의 빠른의미연결 의 산출 단계에서는 단어유사성의 주효과가 유의하지 않았으며, 단 어유사성과 집단의 상호작용도 유의하지 않은 것으로 나타났다. 이 에 대해 추측 가능한 설명으로는 첫째, 비단어 따라말하기가 단기 기억 능력에 의존하여 들은 정보를 즉각적으로 인출하는 것과 달 리 빠른의미연결의 산출 단계는 비단어를 산출하기까지 시간적 간 격이 있으며, 저장된 정보에서 지시 대상과 연결된 음운적 표상을 검색, 인출하는 과정을 거치므로 과제적 요구가 더 높고, 인지적 부 담이 가중된 것에서 비롯되었다는 것이다. 둘째, 저장된 음운적 표 상이 리허설 등의 지지 수단 없이는 손실되기 쉽다는 선행연구의 주장(Baddeley, 2003; Gathercole \& Conway, 1988; Zamuner, Morin-Lessard, Strahm, \& Page, 2016)에 따라 단어유사성이 높은 비 
단어가 어휘지식의 도움을 받아 표상을 확립하고 저장하였더라도 유지하는 데 어려움이 있었을 가능성이 있다. 마지막으로 일반아 동과 단순언어장애 아동 집단 모두 유의하지는 않으나 단어유사성 이 높은 비단어에서 미약하게 더 높은 수행을 보였다는 점을 주목 해볼 때, 본 연구의 결과가 단어학습의 산출에 단어유사성이 영향 을 미치지 않은 것으로 해석하기보다는 두 집단 모두 낮은 점수로 인해 단어유사성의 효과가 감쇄된 현상으로 설명할 수 있다.

두 집단에서 각 실험 과제(비단어 따라말하기, 빠른의미연결 이 해)와 다양한 변인(생활연령, 수용 및 표현어휘력) 간에 상관관계를 살펴본 결과, 단순언어장애 아동 집단은 비단어 따라말하기와 수 용 및 표현어휘력 간의 유의하게 높은 정적 상관을 보였으며, 연령 과도 유의한 정적 상관을 보이는 것으로 나타났다. 이는, 수용 및 표 현어휘력(Alt et al., 2004; Gray, 2004), 연령(Weismer \& Evans, 2002) 이 증가함에 따라 음운정보를 처리하는 능력이 높아진 선행연구의 결과와 일치한다. 이러한 결과들은 기저의 정보처리 기제가 손상된 아동이라 하더라도 음운기억 표상을 형성 및 저장하는 과정에 어 휘지식의 도움을 받으며, 연령이 증가하면서 비단어 따라말하기 수 행에 필요한 능력도 함께 성숙해져 영향을 준다는 사실을 나타낸 다. 반면, 일반아동 집단은 비단어 따라말하기와 빠른의미연결에 서 다양한 변인 간에 어떠한 상관도 보이지 않았는데, 이는 선행연 구에서 일반아동 집단이 비단어 따라말하기의 수행과 수용어휘 력, 연령 간(Lee et al., 2013), 빠른의미연결의 수행과 수용어휘력, 연령 간(Alt et al., 2004; Gray, 2005) 유의한 상관관계를 보였던 것 과 다른 결과이다. 그러나 선행연구에서 만 5세의 아동 집단이 비 단어 따라말하기의 수행과 수용 및 표현 어휘력점수 사이에 유의 한 상관을 보인 것(Gathercole et al., 1999)과 달리 더 어린 연령의 아동의 경우, 음운 정보 처리에 어휘지식을 이용하는 데 어려움이 있었다는 연구자의 보고(Hoover et al., 2010; Zamuner, Gerken, \& Hammond, 2004)에 근거하였을 때, 본 연구의 일반아동 집단에서 각 실험 과제의 수행과 연령, 수용어휘력 간에 어떠한 상관도 보이 지 않았던 결과는 단순언어장애 아동 집단에 비해 일반아동 집단 의 4 세 아동 비율이 더 높았다는 점에 기인했을 가능성을 추측해 볼수 있다.

두 집단에서 각 실험 과제(비단어 따라말하기, 빠른의미연결의 이해)의 비단어 문항별 정반응 평균 점수와 각 비단어의 두음소배 열확률 간의 상관관계를 살펴본 결과, 비단어 따라말하기에서 비 단어의 두음소배열확률이 커질수록 두 집단의 수행력이 높아지는 것으로 나타났다. 이는 일반아동과 단순언어장애 아동 모두 음운 기억 표상을 확립하고 즉각적으로 회상하는 과정에서 비단어의 음 운적 특성에 영향을 받는다는 것을 나타낸다. 빠른의미연결 이해
에서는 일반아동 집단은 비단어 문항별 평균 점수와 비단어의 두 음소배열확률 간의 유의한 상관을 보이지 않았으나 단순언어장애 아동은 유의한 정적 상관을 보이는 것으로 나타났다. 이러한 결과 는 빠른의미연결 이해 단계의 특성으로 설명할 수 있다. 단어학습 과제에서 산출에 비해 이해 단계에서 일관적으로 더 높은 수행을 보였던 선행연구(Alt et al., 2004; Gray, 2003a, 2003b)의 결과들은 단어를 산출하기 위한 준비 과정에 비해 듣고 지시하는 대상을 회 상하여 고르는 과정의 과제적 요구가 훨씬 쉽다는 것을 보여준다. 또한, Gray와 Brinkley (2011)에서 학령전기의 일반아동과 단순언 어장애 아동 모두 빠른의미연결의 이해에서 단어유사성이 높은 비 단어와 단어유사성이 낮은 비단어 간에 유의한 수행 차이가 없었 다는 연구결과로 미루어 보았을 때, 본 연구의 일반아동이 단어학 습의 이해에서 쉬운 과제적 요구로 단어유사성이 높은 비단어에서 뿐만이 아니라 단어유사성이 낮은 비단어에서도 비교적 높은 수행 을 보임으로서 정적 상관이 나타나지 않은 것으로 해석할 수 있다. 또한, 단순언어장애 아동이 단어학습의 이해를 위한 정보를 충분 히 저장할 수 있다는 Dollaghan (1987)의 주장과 달리 본 연구에서 단순언어장애 아동이 단어유사성이 높은 비단어에 비해 단어유사 성이 낮은 비단어의 이해에서 훨씬 더 낮은 수행을 보임으로써 비 단어의 두음소배열확률이 커질수록 수행력이 증가하는 정적 상관 을 보인 것으로 설명할 수 있다. 이러한 결과들은 일반아동과 단순 언어장애 아동 모두 몇 번의 노출로도 단어유사성이 높은 새로운 단어의 표상을 형성, 저장할 수 있으며, 두 집단에서 기저의 처리 과 정이 단어유사성의 영향을 받는다는 사실을 확인하게 한다.

따라서 본 연구의 결과를 종합해보면, 영어뿐만이 아닌 한국어 역시 단어의 음운적 특성인 음소배열확률의 영향을 받는 언어라 는 것을 시사한다. 이는, 언어 기저의 음운 단기기억과 새로운 어휘 의 학습능력을 측정하는 것으로 알려진 비단어 따라말하기와 빠 른의미연결 과제가 이미 습득한 언어적 지식에 영향을 받는다는 강력한 증거를 제공한다. 이러한 결과들은 한국어 비단어를 사용 한 평가 및 중재 활동에서 두음소배열확률의 필요성에 대한 인식 을 증가시킨다는 점에서 중요한 의미를 가진다. 그러나 본 연구의 경우, 빠른의미연결의 산출에서 낮은 점수로 인해 각 집단의 단어 유사성에 따른 수행 차이를 확인하지 못하였다. 따라서 이후 연구 에서는 자극의 수를 줄이거나 제시 단계에서 청각적 제시 횟수를 증가시키는 방법 등을 사용하여 바닥 효과가 나타날 가능성을 줄 임으로써 한국어 빠른의미연결의 산출에서 단어유사성이 미치는 효과를 확인하고, 일반화하는 후속 작업이 필요할 것으로 보인다. 또한, 음운정보를 처리하기 위해 습득된 어휘지식으로부터 정보를 끌어내는 능력이 5세 이후부터 체계화되며(Baddeley, 2003), 더 어 
린 3-4세의 아동은 저장된 표상을 유지하는 데 어려움이 있다는 선 행연구의 보고가 있다(Hoover et al., 2010). 본 연구는 대상 연령이 4-6세의 범위에 있고, 일반아동 집단은 4세 아동의 비율이 단순언 어장애 아동 집단은 6세 아동의 비율이 높아 연령별 비율이 고려되 지 않았다는 제한점이 있었다. 따라서 후속 연구에서는 학령전기 의 연령집단을 3-4세, 5-6세로 세분화하고, 연령별 비율을 맞춤으 로서 연구결과의 타당성을 높이는 작업이 요구된다. 마지막으로 본 연구에서 확인된 단어유사성의 효과가 단어유사성에 의한 것인지 선행연구(Dollaghan \& Campbell, 1998; Gathercole et al., 1991; Storkel, 2001; Storkel \& Rogers, 2000)에서 비단어 따라말하기의 수행에 영향을 미치는 요인으로 보고된 음절 길이나 이웃밀도(neighborhood density)와 같은 다른 음운적 특성에 의한 것인지 살펴 보지 않았다. 따라서 후속연구에서는 단어유사성 외에도 언어 기 저의 처리 과정에 영향을 미칠 수 있는 다른 요인들을 함께 고려함 으로써 연구결과를 더욱 공고히 할 필요성을 제언한다.

\section{REFERENCES}

Alt, M., Meyers, C., \& Figueroa, C. (2013). Factors that influence fast mapping in children exposed to Spanish and English. Journal of Speech, Language, and Hearing Research, 56, 1237-1248.

Alt, M., \& Plante, E. (2006). Factors that influence lexical and semantic fast mapping of young children with specific language impairment. Journal of Speech, Language, and Hearing Research, 49, 941-954.

Alt, M., Plante, E., \& Creusere, M. (2004). Semantic features in fast-mapping: performance of preschoolers with specific language impairment versus preschoolers with normal language. Journal of Speech, Language, and Hearing Research, 47, 407-420.

Archibald, L. M., \& Gathercole, S. E. (2007). Nonword repetition in specific language impairment: more than a phonological short-term memory deficit. Psychonomic Bulletin \& Review, 14, 919-924.

Baddeley, A. (2003). Working memory and language: an overview. Journal of Communication Disorders, 36, 189-208.

Baddeley, A. (2012). Working memory: theories, models, and controversies. Annual Review of Psychology, 63, 1-29.

Baddeley, A., Gathercole, S., \& Papagno, C. (1998). The phonological loop as a language learning device. Psychological Review, 105, 158-173.

Bishop, D. V., \& Adams, C. (1990). A prospective study of the relationship between specific language impairment, phonological disorders and reading retardation. Journal of Child Psychology and Psychiatry, 31, 1027-1050.
Bishop, D. V., North, T., \& Donlan, C. (1996). Nonword repetition as a behavioural marker for inherited language impairment: evidence from a twin study. Journal of child Psychology and Psychiatry, 37, 391-403.

Botting, N., \& Conti-Ramsden, G. (2001). Non-word repetition and language development in children with specific language impairment (SLI). International Journal of Language \& Communication Disorders, 36, 421-432.

Carey, S. (1978). The child as word learner. In M. Halle et al. (Eds.), Linguistic theory and psychological reality (pp. 264-293). Cambridge, MA: MIT Press.

Chiat, S., \& Roy, P. (2007). The Preschool Repetition Test: an evaluation of performance in typically developing and clinically referred children. Journal of Speech, Language, and Hearing Research, 50, 429-443.

Coady, J. A., \& Aslin, R. N. (2004). Young children's sensitivity to probabilistic phonotactics in the developing lexicon. Journal of Experimental Child Psychology, 89, 183-213.

Coady, J. A., Mainela-Arnold, E., \& Evans, J. L. (2013). Phonological and lexical effects in verbal recall by children with specific language impairments. International Journal of Language \& Communication Disorders, 48, 144-159.

Dollaghan, C. A. (1985). Child meets word: "fast mapping" in preschool. Journal of Speech and Hearing Research, 28, 449-454.

Dollaghan, C. A. (1987). Fast mapping in normal and language-impaired children. Journal of Speech and Hearing Disorders, 52, 218-222.

Dollaghan, C., \& Campbell, T. F. (1998). Nonword repetition and child language impairment. Journal of Speech, Language, and Hearing Research, 41, 1136-1146.

Dworzynski, K., \& Howell, P. (2004). Predicting stuttering from phonetic complexity in German. Journal of Fluency Disorders, 29, 149-173.

Edwards, J., \& Lahey, M. (1998). Nonword repetitions of children with specific language impairment: exploration of some explanations for their inaccuracies. Applied Psycholinguistics, 19, 279-309.

Edwards, J., Beckman, M. E., \& Munson, B. (2004). The interaction between vocabulary size and phonotactic probability effects on children's production accuracy and fluency in nonword repetition. Journal of Speech, Language, and Hearing research, 47, 421-436.

Ellis, N. C. (1996). Working memory in the acquisition of vocabulary and syntax: putting language in good order. The Quarterly Journal of Experimental Psychology: Section A, 49, 234-250.

Frisch, S. A., Large, N. R., \& Pisoni, D. B. (2000). Perception of wordlikeness: effects of segment probability and length on the processing of nonwords. Journal of Memory and Language, 42, 481-496.

Gallon, N., Harris, J., \& Van der Lely, H. (2007). Non-word repetition: an in- 
vestigation of phonological complexity in children with Grammatical SLI. Clinical Linguistics \& Phonetics, 21, 435-455.

Gathercole, S. E. (1995). Is nonword repetition a test of phonological memory or long-term knowledge? It all depends on the nonwords. Memory \& Cognition, 23, 83-94.

Gathercole, S. E. (2006). Nonword repetition and word learning: the nature of the relationship. Applied Psycholinguistics, 27, 513-543.

Gathercole, S. E., \& Baddeley, A. D. (1989). Evaluation of the role of phonological STM in the development of vocabulary in children: a longitudinal study. Journal of Memory and Language, 28, 200-213.

Gathercole, S. E., \& Baddeley, A. D. (1990a). The role of phonological memory in vocabulary acquisition: a study of young children learning new names. British Journal of Psychology, 81, 439-454.

Gathercole, S. E., \& Baddeley, A. D. (1990b). Phonological memory deficits in language disordered children: is there a causal connection? Journal of Memory and Language, 29, 336-360.

Gathercole, S. E., \& Baddeley, A. D. (1993). Phonological working memory: a critical building block for reading development and vocabulary acquisition? European Journal of Psychology of Education, 8, 259.

Gathercole, S. E., \& Conway, M. A. (1988). Exploring long-term modality effects: vocalization leads to best retention. Memory \& Cognition, 16, 110119.

Gathercole, S. E., Frankish, C. R., Pickering, S. J., \& Peaker, S. (1999). Phonotactic influences on short-term memory. Journal of Experimental Psychology: Learning, Memory, and Cognition, 25, 84-95.

Gathercole, S. E., Willis, C., Emslie, H., \& Baddeley, A. D. (1991). The influences of number of syllables and wordlikeness on children's repetition of nonwords. Applied Psycholinguistics, 12, 349-367.

Gray, S. (2003a). Diagnostic accuracy and test-retest reliability of nonword repetition and digit span tasks administered to preschool children with specific language impairment. Journal of Communication Disorders, 36, 129-151.

Gray, S. (2003b). Word-learning by preschoolers with specific language impairment: what predicts success? Journal of Speech, Language, and Hearing Research, 46, 56-67.

Gray, S. (2004). Word learning by preschoolers with specific language impairment: predictors and poor learners. Journal of Speech, Language, and Hearing Research, 47, 1117-1132.

Gray, S. (2005). Word learning by preschoolers with specific language impairment: effect of phonological or semantic cues. Journal of Speech, Lan- guage, and Hearing Research, 48, 1452-1467.

Gray, S. (2006). The relationship between phonological memory, receptive vocabulary, and fast mapping in young children with specific language impairment. Journal of Speech, Language, and Hearing Research, 49, 955969.

Gray, S., \& Brinkley, S. (2011). Fast mapping and word learning by preschoolers with specific language impairment in a supported learning context: effect of encoding cues, phonotactic probability, and object familiarity. Journal of Speech, Language, and Hearing Research, 54, 870-884.

Gray, S., Brinkley, S., \& Svetina, D. (2012). Word learning by preschoolers with SLI: effect of phonotactic probability and object familiarity. Journal of Speech, Language, and Hearing Research, 55, 1289-1300.

Gray, S., Pittman, A., \& Weinhold, J. (2014). Effect of phonotactic probability and neighborhood density on word-learning configuration by preschoolers with typical development and specific language impairment. Journal of Speech, Language, and Hearing Research, 57, 1011-1025.

Gupta, P. (2003). Examining the relationship between word learning, nonword repetition, and immediate serial recall in adults. The Quarterly Journal of Experimental Psychology: Section A, 56, 1213-1236.

Hong, S., \& Yim, D. (2014). The assessment of language impairment in bilingual children through learning and memory tasks. Communication Sciences and Disorders, 19, 1-31.

Hoover, J. R., Storkel, H. L., \& Hogan, T. P. (2010). A cross-sectional comparison of the effects of phonotactic probability and neighborhood density on word learning by preschool children. Journal of Memory and Language, 63, 100-116.

Horst, J. S., \& Hout, M. C. (2016). The Novel Object and Unusual Name (NOUN) database: a collection of novel images for use in experimental research. Behavior Research Methods, 48, 1393-1409.

Hwang, M. (2015). Nonword repetition of typically developing children. Communication Sciences \& Disorders, 20, 374-385.

Jackson, E., Leitao, S., \& Claessen, M. (2016). The relationship between phonological short-term memory, receptive vocabulary, and fast mapping in children with specific language impairment. International Journal of Language \& Communication Disorders, 51, 61-73.

Jusczyk, P. W., \& Luce, P. A. (1994). Infants' sensitivity to phonotactic patterns in the native language. Journal of Memory and Language, 33, 630-645.

Kan, P. F., Sadagopan, N., Janich, L., \& Andrade, M. (2014). Effects of speech practice on fast mapping in monolingual and bilingual speakers. Journal of Speech, Language, and Hearing Research, 57, 929-941. 
Kang, J. K., \& Kim, Y. T. (2007). Phonological awareness of preschool children with and without specific language impairment. Korean Journal of Communication \& Disorders, 12, 32-51.

Kim, A., Lee, R., Han, J. S., \& Lee, E. J. (2017). Phonological characteristics of 4-to 5-year-old children in nonword repetition under different phonetic complexity. Communication Sciences \& Disorders, 22, 445-457.

Kim, N. Y., \& Ha, J. W. (2014). Phonological representations in children with articulation and phonological disorders. Communication Sciences \& Disorders, 19, 226-237.

Kim, S. S. (2004). Functional working memory and word learning of Korean children with specific language impairment. Korean Journal of Communication \& Disorders, 9, 78-99.

Kim, Y. T., Hong, G. H., Kim, K. H., Jang, H. S., \& Lee, J. Y. (2009). Receptive \& expressive vocabulary test (REVT). Seoul: Seoul Community Rehabilitation Center.

Lee, E. J., Han, J. S., \& Sim, H. S. (2004). The effects of the phonetic complexity on the disfluencies and the articulation errors of people who stutter. Korean Journal of Communication \& Disorders, 9, 139-156.

Lee, H. J., Kim, Y. T., \& Yim, D. S. (2013). Non-word repetition performance in Korean-English bilingual children. International Journal of Speech-Language Pathology, 15, 375-382.

Lee, S., \& Storkel, H. L. (2012). Parallel activation in bilingual phonological processing. Korean Journal of Communication \& Disorders, 17, 24-35.

Lee, Y. M. (2015). Nonword repetition performance and related factors in school-aged children with cochlear implants. The Journal of Special Children Education, 17, 131-148.

Leonard, L. B. (2014). Children with specific language impairment. Cambridge, MA: MIT Press.

Mackie, C., \& Dockrell, J. E. (2004). The nature of written language deficits in children with SLI. Journal of Speech, Language, and Hearing Research, 47, 1469-1483.

MacRoy-Higgins, M., \& Dalton, K. P. (2015). The influence of phonotactic probability on nonword repetition and fast mapping in 3-year-olds with a history of expressive language delay. Journal of Speech, Language, and Hearing Research, 58, 1773-1779.

MacRoy-Higgins, M., Schwartz, R. G., Shafer, V. L., \& Marton, K. (2013). Influence of phonotactic probability/neighbourhood density on lexical learning in late talkers. International Journal of Language \& Communication Disorders, 48, 188-199.

Marshall, C. R., \& Van Der Lely, H. K. (2007). The impact of phonological complexity on past tense inflection in children with grammatical-SLI. Advances in Speech Language Pathology, 9, 191-203.

McKean, C., Letts, C., \& Howard, D. (2013). Functional reorganization in the developing lexicon: separable and changing influences of lexical and phonological variables on children's fast-mapping. Journal of Child Language, 40, 307-335.

Messer, M. H., Leseman, P. P., Boom, J., \& Mayo, A. Y. (2010). Phonotactic probability effect in nonword recall and its relationship with vocabulary in monolingual and bilingual preschoolers. Journal of Experimental Child Psychology, 105, 306-323.

Metsala, J. L. (1997). An examination of word frequency and neighborhood density in the development of spoken-word recognition. Memory \& Cognition, 25, 47-56.

Moon, S. B., \& Byun, C. J. (2003). Korean Kaufman assessment battery for children (K-ABC). Seoul: Hakjisa.

Munson, B. (2001). Phonological pattern frequency and speech production in adults and children. Journal of Speech, Language, and Hearing Research, 44, 778-792.

Munson, B., Edwards, J., \& Beckman, M. E. (2005). Relationships between nonword repetition accuracy and other measures of linguistic development in children with phonological disorders. Journal of Speech, Language, and Hearing Research, 48, 61-78.

Munson, B., Kurtz, B. A., \& Windsor, J. (2005). The influence of vocabulary size, phonotactic probability, and wordlikeness on nonword repetitions of children with and without specific language impairment. Journal of Speech, Language, and Hearing Research, 48, 1033-1047.

Nash, M., \& Donaldson, M. L. (2005). Word learning in children with vocabulary deficits. Journal of Speech, Language, and Hearing Research, 48, 439458.

National Institute of Korean Language. (2002). Modern Korean usage frequency survey. Seoul: Author.

Paradis, J., Emmerzael, K., \& Duncan, T. S. (2010). Assessment of English language learners: using parent report on first language development. Journal of Communication Disorders, 43, 474-497.

Rice, M. L., Buhr, J. C., \& Nemeth, M. (1990). Fast mapping word-learning abilities of language-delayed preschoolers. Journal of Speech and Hearing Disorders, 55, 33-42.

Rice, M. L., Buhr, J., \& Oetting, J. B. (1992). Specific-language-impaired children's quick incidental learning of words: the effect of a pause. Journal of Speech, Language, and Hearing Research, 35, 1040-1048. 
Roy, P., \& Chiat, S. (2004) A prosodically controlled word and nonword repetition task for 2-to 4-year-olds evidence from typically developing children. Journal of Speech, Language, and Hearing Research, 47, 223-234.

Saito, A., Yoshimura, T., Itakura, T., \& Ralph, M. A. L. (2003). Demonstrating a wordlikeness effect on nonword repetition performance in a conduction aphasic patient. Brain and Language, 85, 222-230.

Shin, J. (2005). Bi-phoneme frequency of Korean: based on spontaneous speech. Korean Linguistics, 28, 81-109.

Shin, J. (2008). Phoneme and syllable frequencies of Korean based on the analysis of spontaneous speech data. Korean Journal of Communication \& Disorders, 13, 193-215.

Shin, J., \& Cha, J. (2003). Korean sound system. Seoul: Hangukmunwhasa.

Stokes, S. F., Wong, A. M., Fletcher, P., \& Leonard, L. B. (2006). Nonword repetition and sentence repetition as clinical markers of specific language impairment: the case of Cantonese. Journal of Speech, Language, and Hearing Research, 49, 219-236.

Storkel, H. L. (2001). Learning new words phonotactic probability in language development. Journal of Speech, Language, and Hearing Research, 44, 13211337.

Storkel, H. L. (2003). Learning new words II: phonotactic probability in verb learning. Journal of Speech, Language, and Hearing Research, 46, 1312-1323.

Storkel, H. L. (2004). Methods for minimizing the confounding effects of word length in the analysis of phonotactic probability and neighborhood density. Journal of Speech, Language, and Hearing Research, 47, 1454-1468.

Storkel, H. L., \& Hoover, J. R. (2010). An online calculator to compute phonotactic probability and neighborhood density on the basis of child corpora of spoken American English. Behavior Research Methods, 42, 497506.

Storkel, H. L., \& Lee, S. Y. (2011). The independent effects of phonotactic probability and neighbourhood density on lexical acquisition by preschool children. Language and Cognitive Processes, 26, 191-211.

Storkel, H. L., \& Maekawa, J. (2005). A comparison of homonym and novel word learning: the role of phonotactic probability and word frequency. Journal of Child Language, 32, 827-853.

Storkel, H. L., \& Rogers, M. A. (2000). The effect of probabilistic phonotactics on lexical acquisition. Clinical Linguistics \& Phonetics, 14, 407-425.

Tattersall, P. J., Nelson, N. W., \& Tyler, A. A. (2015). Associations among nonword repetition and phonemic and vocabulary awareness: implications for intervention. Child Language Teaching and Therapy, 31, 159-171.

Van Bon, W. H., \& Van Der Pijl, J. M. (1997). Effects of word length and word- likeness on pseudoword repetition by poor and normal readers. Applied Psycholinguistics, 18, 101-114.

Vitevitch, M. S., \& Luce, P. A. (1998). When words compete: levels of processing in perception of spoken words. Psychological Science, 9, 325-329.

Vitevitch, M. S., \& Luce, P. A. (1999). Probabilistic phonotactics and neighborhood activation in spoken word recognition. Journal of Memory and Language, 40, 374-408.

Vitevitch, M. S., \& Luce, P. A. (2004). A web-based interface to calculate phonotactic probability for words and nonwords in English. Behavior Research Methods, 36, 481-487.

Vitevitch, M. S., Luce, P. A., Charles-Luce, J., \& Kemmerer, D. (1997). Phonotactics and syllable stress: Implications for the processing of spoken nonsense words. Language and Speech, 40, 47-62.

Weismer, S. E., \& Evans, J. L. (2002). The role of processing limitations in early identification of specific language impairment. Topics in Language Disorders, 22, 15-29.

Weismer, S. E., \& Hesketh, L. J. (1996). Lexical learning by children with specific language impairment: effects of linguistic input presented at varying speaking rates. Journal of Speech, Language, and Hearing Research, 39, 177190.

Weismer, S. E., Tomblin, J. B., Zhang, X., Buckwalter, P., Chynoweth, J. G., \& Jones, M. (2000). Nonword repetition performance in school-age children with and without language impairment. Journal of Speech, Language, and Hearing Research, 43, 865-878.

Weismer, S. E., Venker, C. E., Evans, J. L., \& Moyle, M. J. (2013). Fast mapping in late-talking toddlers. Applied Psycholinguistics, 34, 69-89.

Windsor, J., Kohnert, K., Lobitz, K. F., \& Pham, G. T. (2010). Cross-language nonword repetition by bilingual and monolingual children. American Journal of Speech-Language Pathology, 19, 298-310.

Yang, Y., Yim, D., Kim, S., \& Han, J. (2013). The relationship among receptive vocabulary, non-word repetition, and quick incidental learning in preschoolers with and without delay in vocabulary development. Communication Sciences \& Disorders, 18, 379-391.

Yim, D., Kim, S. Y., \& Yang, Y. (2015). Factor analysis of working memory tasks based on information processing characteristics: predictive factors of receptive vocabulary and quick incidental learning in children with typically developing and receptive vocabulary delay. Communication Sciences \& Disorders, 20, 304-318.

Zamuner, T. S. (2009). Phonotactic probabilities at the onset of language development: speech production and word position. Journal of Speech, Lan- 
guage, and Hearing Research, 52, 49-60.

Zamuner, T. S., Gerken, L., \& Hammond, M. (2004). Phonotactic probabilities in young children's speech production. Journal of Child Language, 31, 515-536.
Zamuner, T. S., Morin-Lessard, E., Strahm, S., \& Page, M. P. (2016). Spoken word recognition of novel words, either produced or only heard during learning. Journal of Memory and Language, 89, 55-67. 
Appendix 1. 각 과제의 비단어 목록과 두음소배열확률

\begin{tabular}{|c|c|c|c|c|}
\hline \multirow{2}{*}{ Nonword repetition } & \multicolumn{2}{|c|}{ High word likeness } & \multicolumn{2}{|c|}{ Low word likeness } \\
\hline & & & & \\
\hline \multirow[t]{2}{*}{2 syllable } & 논잡 & 0.11264 & 눗팸 & 0.00769 \\
\hline & 벙가 & 0.10942 & 찍포 & 0.01785 \\
\hline \multirow[t]{2}{*}{3 syllable } & 재당비 & 0.13611 & 니애콥 & 0.00707 \\
\hline & 도구맙 & 0.07950 & 노웃뺑 & 0.02997 \\
\hline \multirow[t]{2}{*}{4 syllable } & 거남버논 & 0.07085 & 츠모뚜낵 & 0.02650 \\
\hline & 해대버저 & 0.07997 & 움마푸옵 & 0.03417 \\
\hline \multirow[t]{2}{*}{5 syllable } & 보내중머니 & 0.07657 & 째누커무퍼 & 0.01799 \\
\hline & 부지개무니 & 0.11107 & 챙꺼투뚜바 & 0.02726 \\
\hline \multirow[t]{2}{*}{6 syllable } & 무니타낙지노 & 0.13001 & 뽀퍼대터크둔 & 0.03119 \\
\hline & 기디모타매난 & 0.09233 & 니배코대크백 & 0.02944 \\
\hline \multicolumn{5}{|c|}{ Fast mapping } \\
\hline \multirow[t]{2}{*}{2 syllable } & 당무 & 0.10825 & 펏쿠 & 0.00616 \\
\hline & 밴갑 & 0.08518 & 탬툭 & 0.02775 \\
\hline \multirow[t]{2}{*}{3 syllable } & 더부깅 & 0.05670 & 깨차팃 & 0.02738 \\
\hline & 미도갠 & 0.06039 & 빼쿠뜬 & 0.00621 \\
\hline \multirow[t]{2}{*}{4 syllable } & 고노바인 & 0.16364 & 코패즈노 & 0.02810 \\
\hline & 기누바웅 & 0.07510 & 뽀밋커매 & 0.02772 \\
\hline
\end{tabular}

Appendix 2. 빠른의미연결과제의 그림자극 목록(Horst \& Hout, 2016)

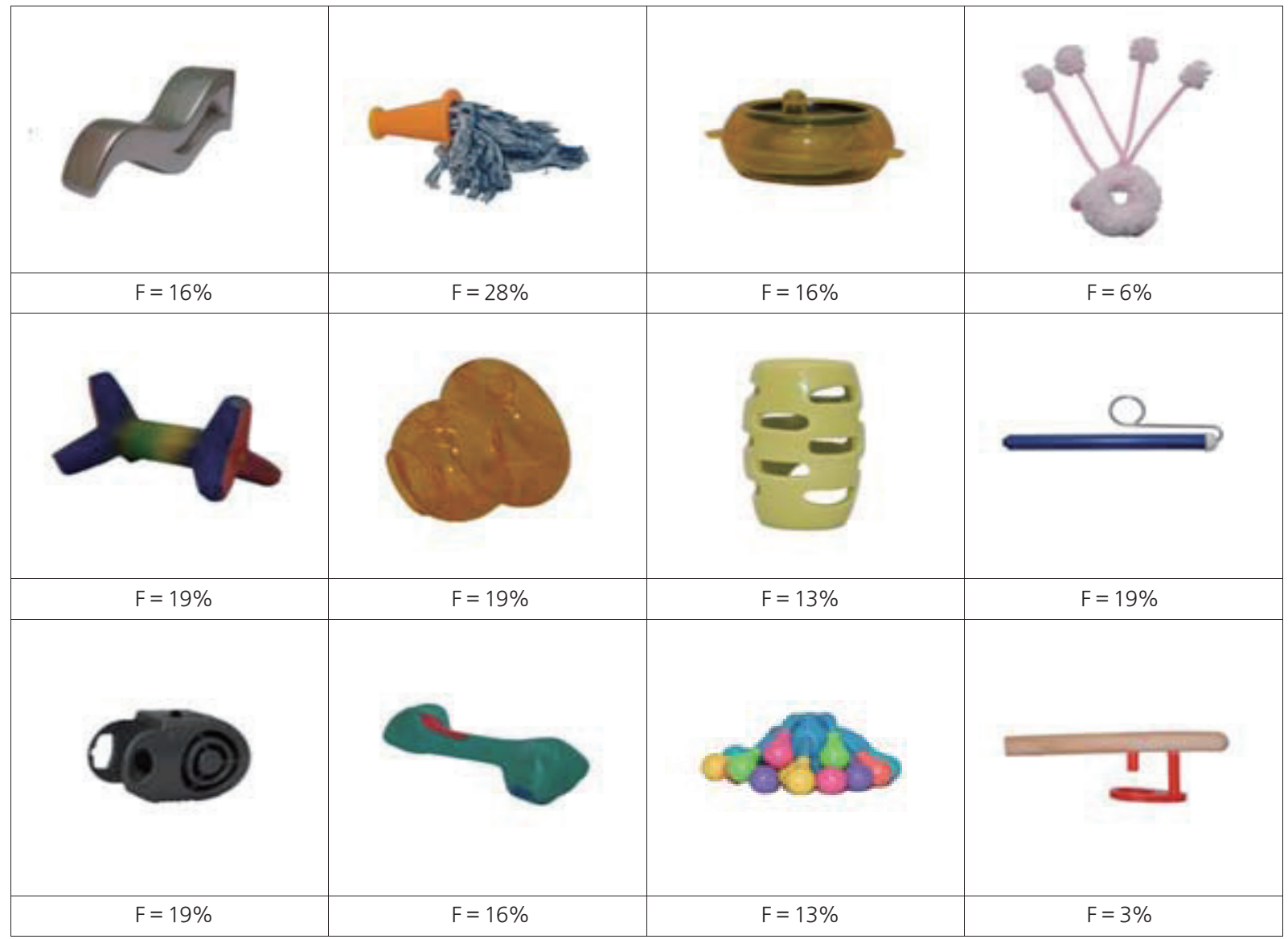




\section{국문초록}

\section{언어적 지식과 한국어 음소배열확률이 비단어 따라말하기 및 빠른의미연결 능력에 미치는 영향}

\section{배경란 · 임동선}

이화여자대학교 대학원 언어병리학과

배경 및 목적: 본 연구는 언어 기저의 처리 과정에서 일반아동 및 단순언어장애 아동이 단어유사성에 따른 수행 차이를 보이는지 알아 보고자 하였으며, 두 집단에서 음운단기기억과 어휘학습 능력이 연령, 어휘력과 같은 다양한 변인이나 비단어의 음소배열확률과 상관 을 보이는지 살펴보고자 하였다. 방법: 서울 및 경기에 거주하는 만 4-6세의 일반아동과 단순언어장애 아동을 대상으로 두음소배열확 률을 조정함으로써 단어유사성에 따른 비단어 따라말하기와 빠른의미연결 과제를 실시하였으며, 통계분석은 분산분석 및 상관분석 을 실시하였다. 결과: 모든 실험 과제에서 집단의 주효과가 유의하였으며, 비단어 따라말하기와 빠른의미연결의 이해에서 단어유사성 의 주효과가 유의하였다. 모든 과제에서 이차상호작용은 나타나지 않았다. 또한, 단순언어장애 아동에 한해 비단어 따라말하기의 수행 과수용 및 표현어휘력, 연령 간의 유의한 상관을 보였다. 비단어 따라말하기에서 단순언어장애 아동과 일반아동의 수행이, 빠른의미연 결의 이해에서 단순언어장애 아동의 수행이 두음소배열확률과 유의한 정적 상관을 나타냈다. 논의 및 결론: 음운단기기억과 어휘학습 능력과 같은 언어 기저의 처리 과정이 한국어 음소배열확률의 영향을 받았음을 보여준다. 또한, 높은 단어유사성에서 이점은 일반아동 과 단순언어장애 아동 집단이 모두 언어적 지식의 영향을 받았음을 나타낸다. 이러한 결과들은 한국어 비단어를 사용한 평가와 중재 에 음소배열확률을 고려해야할 필요성을 제시한다.

핵심어: 단어유사성, 음소배열확률, 언어적 지식, 비단어 따라말하기, 빠른의미연결, 학령 전기

본 논문은 제 1 저자의 석사학위 논문의 일부를 발췌한 것임.

\section{참고문헌}

강진경, 김영태(2007). 취학전 단순언어장애 아동의 음운인식에 관한 연구. 언어청각장애연구, 12, 32-51.

국립국어연구원(2002). 현대 국어 사용 빈도 조사. 서울: 국립국어연구원.

김나연, 하지완(2014). 조음음운장애아동과 일반아동의 음운표상의 질과 음운표상 부호화 능력 비교. 언어청각장애연구, 19, 226-237.

김성수(2004). 단순언어장애 아동의 기능적 작업기억과 낱말 습득 특성. 언어청각장애연구, 9, 78-99.

김아름, 이란, 한진순, 이은주(2017). 조음복잡성에 따른 비단어 따라말하기에서 나타난 4-5세 일반아동의 음운 특성. 언어청각장애연구, 22, 445-457.

김영태, 홍경훈, 김경희, 장혜성, 이주연(2009). 수용·표현어휘력검사(REVT). 서울: 서울장애인종합복지관.

문수백, 변창진(2003). K-ABC 교육· 심리측정도구(Korean-Kaufman assessment battery for children). 서울: 학지사.

신지영(2005). 한국어음소의 전이 빈도 3세-8세 아동의 자유 발화 자료를 바탕으로. 한국어학, 28, 81-109.

신지영(2008). 성인 자유 발화 자료 분석을 바탕으로 한 한국어의 음소 및 음절 관련 빈도. 언어청각장애연구, 13, 193-215.

신지영, 차재은(2003). 우리말 소리의 체계. 서울: 한국문화사.

양윤희, 임동선, 김신영, 한지윤(2013). 학령 전 어휘발달지체 및 일반 아동의 비단어 따라 말하기, 빠른 우연학습과 수용어휘와의 관계. 언어청각장애

연구, 18, 379-391.

이수연, Holly L. Storkel (2012). 이중언어 사용자의 음운처리에 나타나는 두 언어의 병행 활성화. 언어청각장애연구, 17, 24-35.

이영미(2015). 학령기 인공와우 아동의 비단어따라말하기 수행력과 관련 요인 분석. 특수아동교육연구, 17, 131-148.

이은주, 한진순, 심현섭(2004). 조음복잡성이 비유창성과 조음오류에 미치는 영향: 언어청각장애연구, 9, 139-156.

임동선, 김신영, 양윤희(2015). 정보처리 특성에 따른 작업기억 과제의 탐색적 요인분석: 일반아동 및 수용어휘지체 아동의 수용어휘력 및 빠른우연

학습 예측요인. 언어청각장애연구, 20, 304-318.

홍성미, 임동선(2014). 학습 및 기억과제를 통한 이중언어아동의 언어발달지체 평가. 언어청각장애연구, 19, 1-31.

황민아(2015). 일반아동의 비단어 따라말하기. 언어청각장애연구, 20, 374-385. 